\title{
Origin and tectonic significance of the Huangling massif within the Yangtze craton, South China
}

- $\quad$ Wenbin $\mathrm{Ji}^{\mathrm{ab}}$

- $\underline{\text { Wei Lin }}^{\mathrm{a}}$

- Michel Faure $^{\mathrm{c}}$

- $\quad \underline{\text { Yang } \mathrm{Chu}^{\mathrm{a}}}$

- ${\text { Lin } \mathrm{Wu}^{\mathrm{ab}}}^{\mathrm{Ya}}$

- Fei Wang $^{\mathrm{a}}$

- Jun Wang ${ }^{\mathrm{ab}}$

- Qingchen Wang

- $\quad{ }^{a}$ State Key Laboratory of Lithospheric Evolution, Institute of Geology and Geophysics, Chinese Academy of Sciences, Beijing 100029, China

- ${ }^{\mathrm{b}}$ University of the Chinese Academy of Sciences, Beijing 100049, China

- $\quad{ }^{\mathrm{c}}$ Institut des Sciences de la Terre d'Orléans, Université d'Orléans-CNRS, 1A rue de la Férollerie, 45071 Orléans, France

\begin{abstract}
As the oldest exposed basement and the typical sedimentary cover of the Yangtze craton, the Huangling massif is a suitable place to decipher the tectonics of South China block. Structural analysis shows that the Huangling massif has an elliptic domal shape with $\mathrm{N}-\mathrm{S}$ striking long axis, an asymmetric antiform with a steep western flank and a gentle eastern flank. There, three litho-tectonic units are recognized, from inner to outer parts: (1) ArcheanPaleoproterozoic metamorphic rocks intruded by Neoproterozoic granitoids; (2) Neoproterozoic to Jurassic sedimentary envelope around the dome core; (3) Cretaceous terrigeneous alluvial-fluvial deposits, unconformably overlying the dome flanks. Coeval with the uplifting of the massif, the pre-Cretaceous strata on the western and eastern flanks of the Huangling massif were involved in a series of folds with nearly $\mathrm{N}-\mathrm{S}$ axes and layer-parallel slip structures with top-to-the-W and top-to-the-E motion, respectively. The subsequent brittle normal faulting controlled the deposition of the graben or half-graben basins on both flanks. Cooling history reveals that the Huangling massif underwent uplifting between $160 \mathrm{Ma}$ and $110 \mathrm{Ma}$ with an average cooling rate of $2-3{ }^{\circ} \mathrm{C} / \mathrm{Ma}$. Moreover, the Huangling area was not significantly affected by the Early Paleozoic and Triassic orogenies of South China. Comparable with the contemporaneous extensional structures, such as metamorphic core complexs, syntectonic plutons bounded by ductile normal faults, and rift-related basins in eastern China, it is proposed that the Huangling massif, might be an extensional structure controlled by a weak crustal extension. In this case, it will represent the western front of the Late Mesozoic lithospheric thinning in entire eastern China. However the compressional model cannot be ruled out.
\end{abstract}

Keywords : Huangling massif; Structural analysis; Cooling and uplifting history; Late Mesozoic tectonics; South China 


\section{Introduction}

The tectonic evolution of the South China block (SCB, Fig. 1) is a significant issue for understanding the geological framework of the Eurasian continent. Although controversies existed during the last decades, it is now generally accepted that the amalgamation of the Yangtze block and the Cathaysia block along the Jiangnan or Sibao orogen created the SCB during the early stage of the Neoproterozoic, corresponding to the assembly of Rodinia supercontinent (Huang, 1978, Zhang et al., 1984, Shui, 1988, Hsü et al., 1988, Hsü et al., 1990, Guo et al., 1989, Chen et al., 1991, Gilder et al., 1991, Charvet et al., 1996, Shu and Charvet, 1996, Li, 1998, Chen, 1999, Li et al., 2004 and Li et al., 2009 and references therein). During the Phanerozoic, the SCB experienced three main tectonic events: (1) the Early Paleozoic intracontinental orogeny along the Wuyi-Baiyun-Yunkai belt, corresponding to the closure of the Neoproterozoic Nanhua rift (Lin et al., 2008, Faure et al., 2009, Charvet et al., 2010, Li et al., 2010 and Y.J. Wang et al., 2010); (2) a series of Early Mesozoic orogenies around the periphery of the SCB, such as the Qinling-Dabie-Sulu orogenic belt to the north (e.g. Mattauer et al., 1985, Faure et al., 1999, Faure et al., 2003, Hacker et al., 2000, Ratschbacher et al., 2000, Ratschbacher et al., 2003 and Lin et al., 2009); the Songpan-Ganzi fold belt and Longmenshan fold-thrust belt to the west (Burchfiel et al., 1995, Chen and Wilson, 1996, Roger et al., 2010 and Yan et al., 2011); the Indosinian orogenic belt to the south (Carter et al., 2001, Carter and Clift, 2008, Wang et al., 2007, Lepvrier et al., 2008 and Lin et al., 2008), as well as the intracontinental Xuefengshan-Jiuling belt in the center of the SCB (Wang et al., 2005, Shu et al., 2008, Chu et al., 2012a, Chu et al., 2012b, Chu et al., 2012c and Chu and Lin, 2013, this issue); (3) the Late Mesozoic tectonicmagmatic events, represented by widespread intracontinental compression and extension (Lin et al., 2000, Yan et al., 2003, Shu et al., 2009, Y.Q. Zhang et al., 2009, Zhang et al., 2012, Zhu et al., 2010, Li et al., 2011, Li et al., 2013, Hu et al., 2012 and Shi et al., 2012), as well as massive granitoids and volcanic rocks in the southeast (e.g. Li, 2000, Zhou and Li, 2000, Zhou et al., 2006 and $\mathrm{Li}$ and $\mathrm{Li}, 2007$ ). 


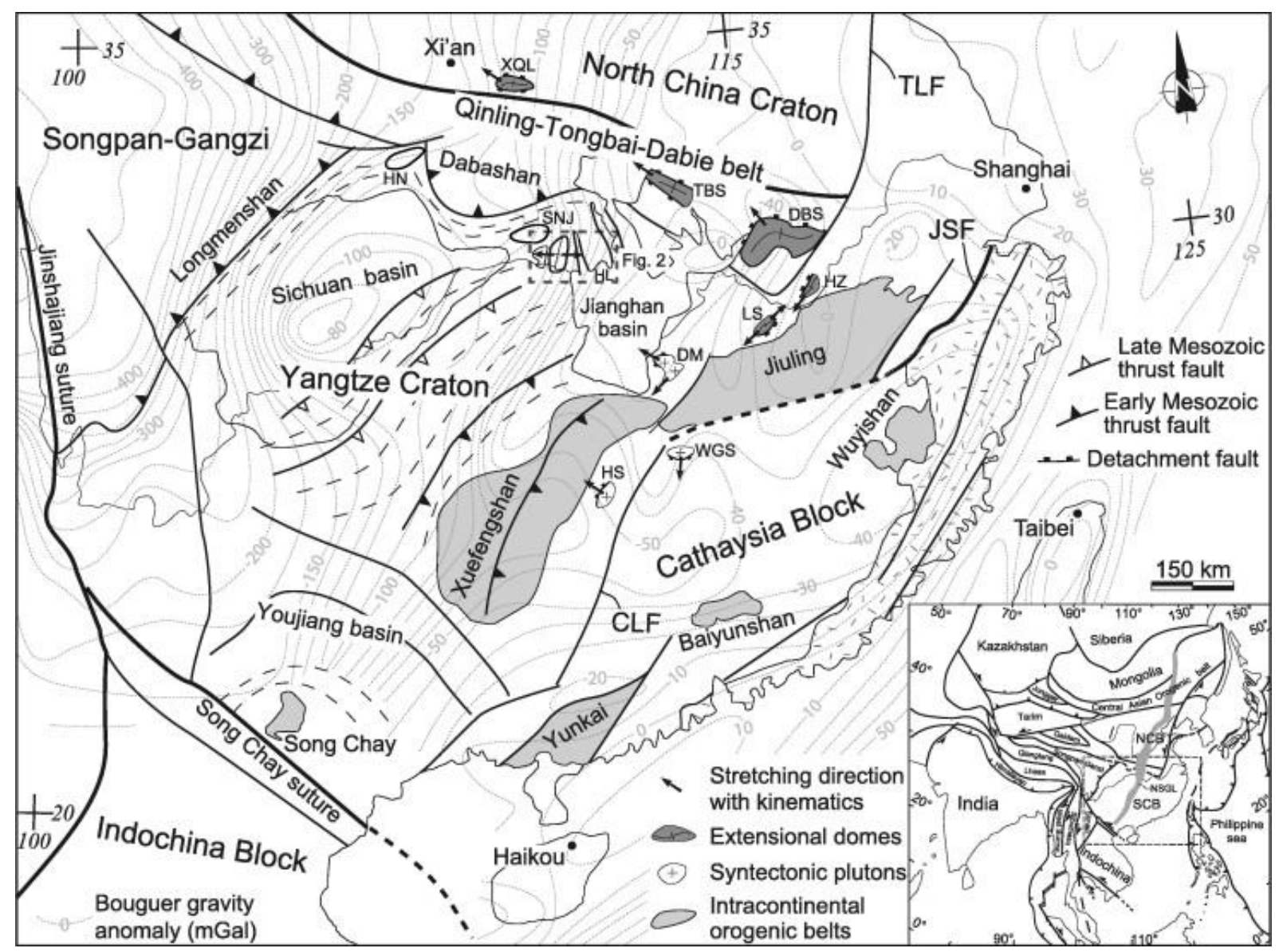

Fig. 1. : Tectonic map of the South China block and the location of the Huangling massif (modified after Faure et al. (2009)). The Bouguer gravity anomaly is projected on base map. NCC, North China Craton; SCB, South China block; NSGL, N-S Gravity Lineament of China; JSF, Jiangshan-Shaoxing Fault, represents the Neoproterozoic suture between the Yangtze block and Cathaysia block; CLF, Chenzhou-Linwu fault; TLF, Tan-Lu Fault; HN, Hannan massif; SNJ, Shennongjia massif; HL, Huangling massif. Late Mesozoic extensional structures: XQL, Xiaoqinling MCC (Zhang and Zheng, 1999); TBS, Tongbaishan anticline (Our field survey); DBS, Dabieshan MCC (Ratschbacher et al., 2000, Ji et al., 2011 and Y.S. Wang et al., 2011); LS, Lushan massif (Lin et al., 2000); HZ, Hongzhen MCC (Zhu et al., 2010); WGS, syntectonic granite in the Wugongshan dome (Faure et al., 1996 and Wang et al., 2001); DM, Dayunshan-Mufushan syntectonic granite (Yu and Ye, 1998; our field survey); HS, Hengshan syntectonic granite (our field survey, Zhang et al., 2012).

The Jurassic-Cretaceous epoch is a complex transition period of tectonic regime in the entire eastern Eurasia from compression to extension. In eastern China, a large number of Late Mesozoic extensional structures have been documented, such as metamorphic core complexes (MCCs), metamorphic or magmatic domes and syntectonic plutons bounded by ductile normal faults, which indicate a continental-scale extension along the eastern Eurasian continental margin (e.g. Lin and Wang, 2006, T. Wang et al., 2011 and Lin et al., 2013). It is also supported by numerous rift basins and giant igneous events (e.g. Ren et al., 2002, Meng et al., 2003, Wu et al., 2005, Yang et al., 2008 and Li et al., 2012). However, the geodynamic mechanism of this Late Mesozoic "lithospheric thinning" or "Destruction" of the North China Craton (NCC, Fig. 1) in eastern China are still disputed (for reviews, see Menzies et al., 2007, Wu et al., 2008 and Zhu et al., 2011 and references therein). 
In the SCB, after the Triassic continental subduction of the SCB beneath the NCC, the Late Jurassic-Early Cretaceous magmatism and intracontinental extensional basins were notable geological features, which indicate that the SCB probably also experienced lithospheric thinning or regional extension (e.g. Gilder et al., 1996, Li, 2000, Zhou and Li, 2000, Zhou et al., 2006, Li and Li, 2007, Shu et al., 2009 and Wei et al., 2013, this issue). However, the tectonics related to such an extensional setting is poorly understood, since only few extensional structures were reported within the SCB (Fig. 1), namely Tongbaishan anticline (our field survey), the Dabieshan MCC (Ratschbacher et al., 2000, Ji et al., 2011 and Y.S. Wang et al., 2011), the Hongzhen MCC (Zhu et al., 2010), the Lushan dome (Lin et al., 2000), syntectonic granite in the Wugongshan dome (Faure et al., 1996 and Wang et al., 2001), Dayunshan-Mufushan syntectonic granite (Yu and Ye, 1998; our field survey); Hengshan syntectonic granite (our field survey; Zhang et al., 2012). From the view of the eastern China, most of this Late Mesozoic extensional structures were superimposed upon the pre-existing orogenic belts (Central Asian orogenic belt, Yinshan-Yanshan belt, and QinlingDabie-Sulu orogenic belt) or along the crustal-scale faults (e.g. Tan-Lu fault), and rarely developed in inland area of stable craton (Lin and Wang, 2006, T. Wang et al., 2011 and Lin et al., 2013 and references therein).

The Huangling massif (also named Huangling anticline or Huangling dome) is located at the middle Yangtze craton. As an exposed area of the oldest basement of the Yangtze craton and its typical sedimentary sequences from Neoproterozoic to Cenozoic, it provides a suitable place to understand the tectonic evolution of the SCB (Fig. 1). In spite of numerous previous studies focused on petrology, geochemistry, geochronology, sedimentology of the metamorphic basement, sedimentary cover, and granitoids (Ma et al., 1984, Ma et al., 1997, Ma et al., 2002, Feng et al., 1991, Ling et al., 1998, Ling et al., 2001, Ling et al., 2006, Gao et al., 1999, Gao et al., 2011, Qiu et al., 2000, Li et al., 2002, Li et al., 2004, Li et al., 2007, Li et al., 2008, Condon et al., 2005, Liu et al., 2008, Gao and Zhang, 2009, Zhang et al., 2006a, Zhang et al., 2006b, Zhang et al., 2006c, Zhang et al., 2008, S.B. Zhang et al., 2009, Meng and Li, 2003, Zhao et al., 2010 and Chen et al., 2013), as well as the crustal structure (Z.J. Zhang et al., 2009), the structural geology and tectonic framework of the Huangling massif are rarely documented (Zhang, 1986 and Jiang et al., 2002; Ge et al., 2010 and J. Wang et al., 2010). The following questions deserve attention: when and how the Huangling massif formed? Was the entire uplifting process controlled by a single event or multiphase events? How the Huangling massif recorded the different tectonic events recognized in the SCB, especially the Late Mesozoic transition of tectonic regimes in eastern China?

In this work, we present new structural and thermochronological data on the Huangling massif in order to reveal its geometry, kinematics and tectono-thermal evolution. The results provide not only new insights to decipher the complex tectonic evolution of the SCB, but also an enlightenment to understand the Late Mesozoic tectonics of eastern China.

\section{Geological overview of the Huangling massif}

As an antiformal structure that crops out near the north margin of the SCB, the Huangling massif is located to the northwest of Yichang city (Fig. 2). Unlike the NCC, where the Archean to Paleoproterozoic rocks are well exposed, Precambrian rocks of the SCB are dominated by Neoproterozoic ages and exposed sporadically below the thick cap of the Phanerozoic sedimentary cover. Until now, the oldest rocks in the SCB are exposed in the Huangling massif with ages of 3.2-3.3 Ga (Jiao et al., 2009 and Gao et al., 2011). The core of the massif referred to as the Archean-Paleoproterozoic Kongling complex, mainly consists of 
orthogneiss, amphibolite, serpentinite, metapelite, quartzite, marble, as well as rare granulite (BGMRHB, 1990, Ma et al., 1997 and Gao et al., 1999). Available geochronological data yield zircon protolith ages of 2.90-2.98 Ga for most of metamorphic igneous rocks, detrital populations of 2.7-3.3 Ga for the metasedimentary rocks, as well as two significant metamorphic events at ca. 2.70-2.75 Ga and ca. 1.9-2.1 Ga (Ling et al., 1998, Ling et al., 2001, Qiu et al., 2000, Zhao et al., 2006, Zhang et al., 2006a, Zhang et al., 2006b, Gao et al., 2011 and Chen et al., 2013). More recently, the ultramafic-mafic rocks (ca. 1100-985 Ma) exposed in the southwestern part of the Huangling massif were considered as a Grenvillian ophiolite (Peng et al., 2012).

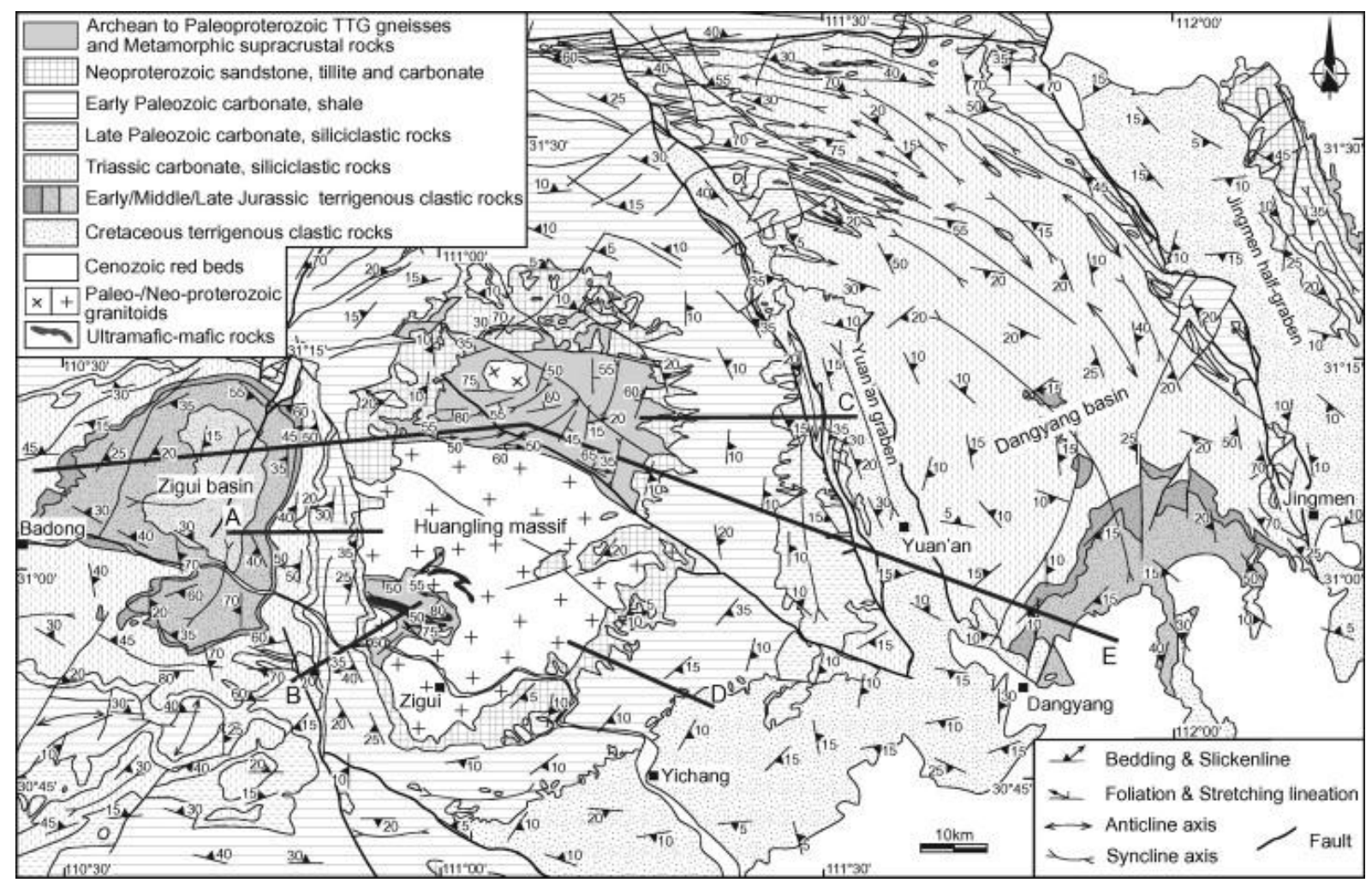

Fig. 2. : Geological and structural map of the Huangling massif.

The Kongling complex was intruded by the large Neoproterozoic Huangling granitic pluton (Fig. 2). The Huangling granitoids occupy almost two thirds of the dome core. They are subdivided into four magmatic suites in terms of lithology, such as trondhjemite-granodiorite, quartz diorite-tonalite, monzogranite-quartz monzodiorite, as well as mafic-felsic dikes (Ma et al., 2002). Available geochronological data yield a wide range of 794-837 Ma for the emplacement age of Huangling granitoids (Ma et al., 1984, Ma et al., 2002, Feng et al., 1991, Li et al., 2002, Li et al., 2004, Ling et al., 2006, Gao and Zhang, 2009, Zhang et al., 2008 and S.B. Zhang et al., 2009).

In the Huangling massif, both the Kongling complex and the Huangling granitoids were unconformably overlain by Neoproterozoic strata. As a stable sedimentary platform, Neoproterozoic-Jurassic sedimentary series on the domal flanks are roughly continuous, except several slight discontinuities caused by the Early Paleozoic and Early Mesozoic tectonic events (Fig. 3). Some stratotype sections were established in the study area (BGMRHB, 1990). The Neoproterozoic strata, from bottom upward, are mainly composed of 
sandstone (Liantuo Formation), tillite (Nantuo Formation), and carbonate rocks (Doushantuo and Dengying Formations). The Cambrian to Early Triassic sedimentary series mainly consists of littoral to neritic facies carbonate and siliciclastic rocks. The most significant lithologies, as synthesized in Fig. 3, include Cambrian carbonate rocks; Ordovician limestone and minor shale; Lower-Middle Silurian shale, mudstone and minor limestone; Middle-Upper Devonian sandstone and siltstone; Middle Carboniferous sandstone, siltstone and limestone; Permian chert-bearing limestone, and sandstone with coal seams in the bottom; Lower Triassic limestone, locally with shale in the bottom. A few hiatuses existed during the Middle Silurian to Middle Devonian as well as the Carboniferous periods. The Middle Triassic strata are dominated by paralic facies limestone, siltstone and shale. A local discontinuity between the Middle and Lower Triassic represents a significant transition of the sedimentary environment and facies from marine to continental (Meng and Li, 2003, Li et al., 2008 and Zhao et al., 2010). The Upper Triassic and Jurassic deposits are fluvial-lacustrine sandstone, siltstone, mudstone and coal seams. It is worthy to be mentioned that the Zigui and Dangyang intracontinental basins that crop out on the western and eastern flanks of the Huangling massif, respectively, were considered to be belong to a single basin system developed in the northern Yangtze craton during the Late Triassic to Middle Jurassic (Liu et al., 2005). The Lower and Upper Cretaceous formations consist of alluvial-fluvial conglomerate, sandstone, siltstone and mudstone that unconformably overlie the older series on two flanks of the Dangyang basin, and the southwestern flank of the Huangling massif (Fig. 2 and Fig. 4). 


\begin{tabular}{|c|c|c|c|c|c|c|}
\hline Era & Column & $\begin{array}{l}\text { Thickness } \\
(\mathrm{m})\end{array}$ & Major lithology & \multicolumn{3}{|l|}{ Notes } \\
\hline$Q$ & & $0 \sim 100$ & Loose deposits & \multirow{2}{*}{\multicolumn{2}{|c|}{ N/E angular unconformity }} & \\
\hline $\mathrm{N}$ & & $10 \sim 50$ & Mudstone, siltstone & & & \\
\hline$E$ & 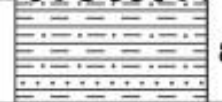 & $800 \sim 2000$ & $\begin{array}{l}\text { Siltstone, mudstone, } \\
\text { sandstone } \\
\text { (Mainly in the Jianghan basin) }\end{array}$ & \multirow{3}{*}{$J_{3} / K_{1}$ angular unconformity } & & \\
\hline K & 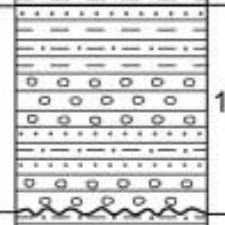 & $1000 \sim 4800$ & $\begin{array}{l}\mathrm{K}_{2} \text { : Conglomerate, } \\
\text { sandstone, interbedded } \\
\text { siltstone and mudstone } \\
\mathrm{K}_{1} \text { : Conglomerate, } \\
\text { sandstone intercalated with } \\
\text { siltstone } \\
\text { (Mainly in the SE and E flanks) }\end{array}$ & & 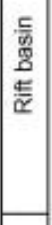 & \\
\hline$J$ & 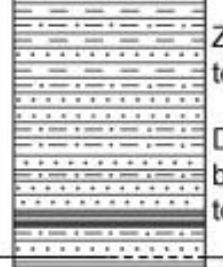 & $\begin{array}{l}\text { Zigui basin: } \\
\text { total }>6500 \\
\text { Dangyang } \\
\text { basin: } \\
\text { total }>1000\end{array}$ & $\begin{array}{l}\text { Sandstone, siltstone, } \\
\text { mudstone, shale, } \\
\text { coal seams in the lower part }\end{array}$ & & 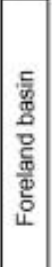 & \\
\hline T & 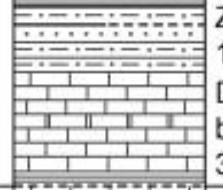 & $\begin{array}{l}\text { Zigui basin: } \\
1100 \sim 3300 \\
\text { Dangyang } \\
\text { basin: } \\
300 \sim 1600\end{array}$ & $\begin{array}{l}\text { Siltstone and shale in the } \\
\text { upper part; } \\
\text { thin-bedded limestone in the } \\
\text { lower part, locally shale in } \\
\text { the bottom }\end{array}$ & \multirow[t]{4}{*}{$T_{3} / T_{2}$ local disconformity } & & \\
\hline $\mathrm{P}$ & 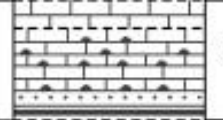 & $300 \sim 580$ & $\begin{array}{l}\text { Thick-bedded chert-bearing } \\
\text { limestone; sandstone with } \\
\text { coal seams in the bottom }\end{array}$ & & & \\
\hline $\mathrm{C}_{2}$ & 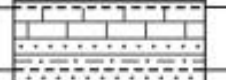 & $6 \sim 156$ & $\begin{array}{l}\text { Limestone, sandstone, } \\
\text { siltstone }\end{array}$ & & & \\
\hline $\mathrm{D}_{2-3}$ & 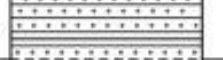 & $1 \sim 160$ & Sandstone, minor shale & & & \\
\hline $\mathrm{S}_{1-2}$ & 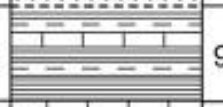 & $910 \sim 1500$ & $\begin{array}{l}\text { Shale, mudstone, minor } \\
\text { thin-bedded limestone }\end{array}$ & $\mathrm{D}_{2} / \mathrm{S}_{2}$ hiatus & E & $\begin{array}{l}\frac{n}{0} \\
\frac{\Phi}{\infty} \\
\frac{\Phi}{0}\end{array}$ \\
\hline $\mathrm{O}$ & 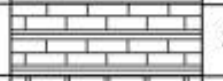 & $300 \sim 500$ & $\begin{array}{l}\text { Thin-medium bedded } \\
\text { limestone, interlayered shale }\end{array}$ & & $\frac{F}{\frac{7}{0}}$ & $\frac{\substack{\frac{\pi}{\pi} \\
\Sigma}}{2}$ \\
\hline$\epsilon$ & 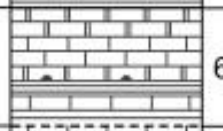 & $650 \sim 1250$ & $\begin{array}{l}\text { Dolomite, limestone, } \\
\text { shale }\end{array}$ & & & \\
\hline \multirow{4}{*}{$\mathrm{Pt}_{3}$} & 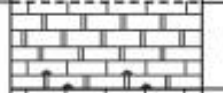 & $60 \sim 650$ & $\begin{array}{l}\text { Dolomite and limestone } \\
\text { (Dengying Fm.) }\end{array}$ & & & \\
\hline & 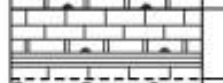 & $60 \sim 310$ & $\begin{array}{l}\text { Limestone, dolomite, minor } \\
\text { shale (Doushantuo } \mathrm{Fm} \text {.) }\end{array}$ & \multirow{2}{*}{$\begin{array}{l}\text {-ca. 551Ma (Condon et al., 2005) } \\
\text {-ca. } 635 \mathrm{Ma} \text { (Condon et al., 2005) }\end{array}$} & & \\
\hline & & $0 \sim 150$ & Tillite (Nantuo Fm.) & & & \\
\hline & $\therefore$ & $0 \sim 250$ & $\begin{array}{l}\text { Sandstone, conglomerate in } \\
\text { the bottom (Liantuo Fm.) }\end{array}$ & \multirow{2}{*}{$\begin{array}{l}\text { - ca. 724Ma (Gao \& Zhang, 2009) } \\
\text { ca. 748Ma (Ma et al., 1984) } \\
\text { Cover/basement } \\
\text { angular unconformity } \\
\text { Kongling complex, intruded by the } \\
\text { Huangling granitoids ( } 820 \sim 800 \mathrm{Ma} \text { ) }\end{array}$} & 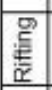 & \\
\hline$\frac{5}{\frac{5}{4}}$ & $\underbrace{++}_{2+2}$ & & $\begin{array}{l}\text { TTG gneisses, metamorpic } \\
\text { supracrustal rocks; } \\
\text { Ultramafic-mafic rocks }\end{array}$ & & & \\
\hline 2 & $\begin{array}{l}\text { Metamorphic } \\
\text { basement }\end{array}$ & & 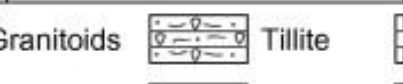 & Limestone & & \\
\hline$\frac{10 \%}{\frac{0}{0} 0}$ & Conglomerate & 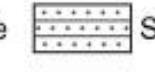 & Sandstone & 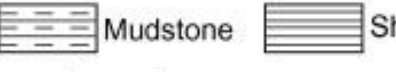 & & \\
\hline 4 & Chert & & Coal seam Disconfor & nity $\leadsto$ Angular unconfor & & \\
\hline
\end{tabular}

Fig. 3. : Stratigraphic column of the Huangling area (BGMRHB, 1990). The boundary ages of the Neoproterozoic Liantuo, Nantuo and Duoshantuo Formations were dated by zircon U- $\mathrm{Pb}$ of volcanic ash or tuff beds (Ma et al., 1984, Condon et al., 2005 and Gao and Zhang, 2009). 

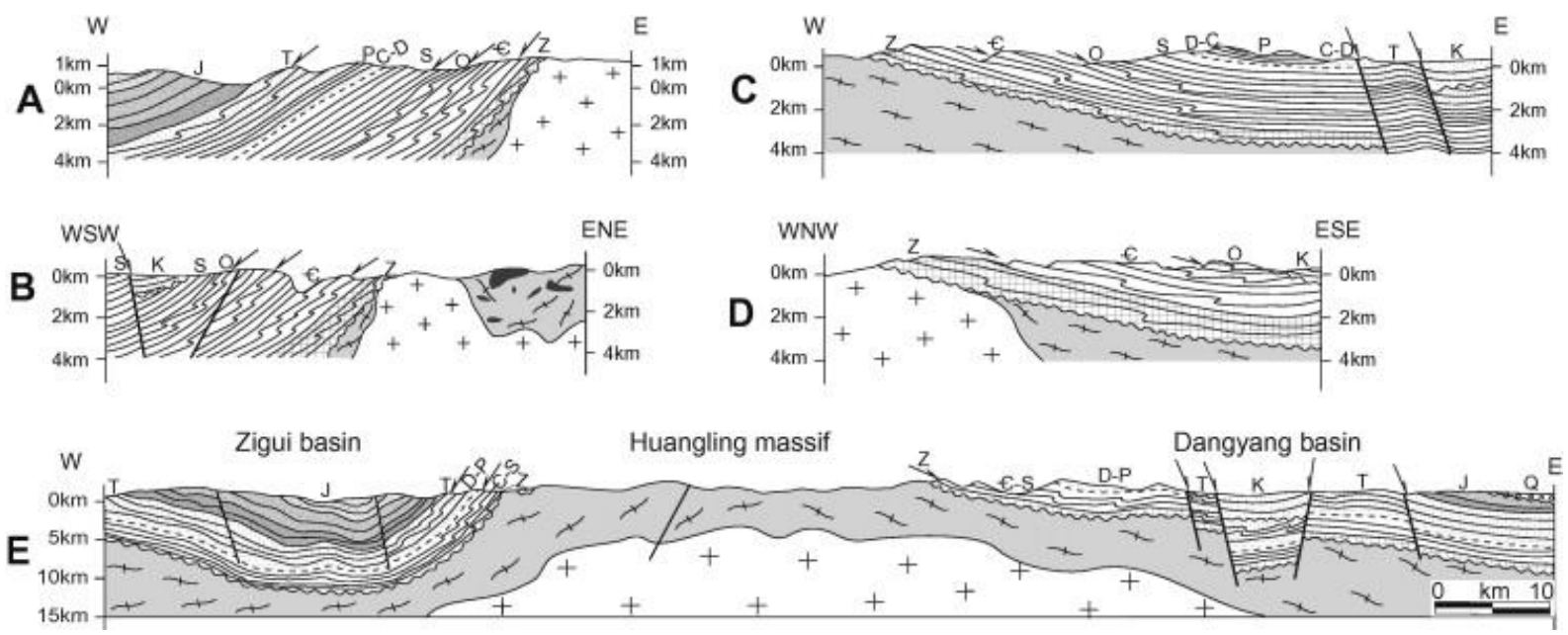

Fig. 4. : Cross-sections across the Huangling massif (locations in Fig. 2). (A-D) Crosssections of the western and eastern sides of the massif in different locations. (E) General cross-section traversing the Zigui basin, Huangling massif and Dangyang basin.

As already stated, the SCB experienced complex geological history. Previous workers interpreted the Huangling massif was developed in a variety of tectonic settings. (1) With emphasis on the Huangling massif as an inherited paleo-uplift from Neoproterozoic to Jurassic, Zhang (1986) considered that the Triassic and Cretaceous events triggered its uplift. (2) On the basis of the regional discontinuities, Jiang et al. (2002) suggested that the Huangling massif underwent several stages of uplift and subsidence throughout the Neoproterozoic to Triassic times. (3) From the view of the tectonic evolution of the Jianghan basin (Fig. 1), Dai (1996) and Xu et al. (2004) interpreted that the Huangling massif originated from the westward escape, due to the Early Mesozoic collision of the NCC-SCB in a scissor-like fashion. (4) Ge et al. (2010) argued that the Huangling massif experienced a preCretaceous compression, and a Late Cretaceous to Paleogene extensional uplifting as a metamorphic core complex. (5) According to their understanding of the regional tectonics of the Qinling-Dabie orogenic belt, Wang et al. (2003) proposed that the Mesozoic northward indentation of the SCB into the NCC to the west, coeval with a clockwise rotation of the Sichuan basin, resulted in eastward extrusion. The Hannan (HN), Shennongjia (SNJ), and Huangling (HL) massifs (Fig. 1) were regarded as indenters formed during this process. The Mesozoic tectono-sedimentary development of the northwest Sichuan basin is also thought to have pertained during the SCB clockwise rotation (Meng et al., 2005). Alternatively, several authors suggested that these three basement uplifts (HN, SNJ, and HL) as backstops played a significant role in formation of the Dabashan orocline (Fig. 1), which was controlled by a SW-directed thrusting during the Middle-Late Jurassic to Early Cretaceous (Hu et al., 2012, Shi et al., 2012 and Li et al., 2013).

\section{Structural analysis of the Huangling massif}

\subsection{Bulk architecture and litho-tectonic units}

Field survey shows that the bulk architecture of the Huangling massif is an asymmetric elliptic dome with a $15^{\circ} \mathrm{NE}$ striking long axis, with long and short axes lengths of about $73 \mathrm{~km}$ and $36 \mathrm{~km}$, respectively. The Zigui basin to the west is a syncline, and the Dangyang basin is a synclinorium located to the east (Fig. 2). The Yuan'an graben and Jingmen half- 
graben superimpose on the two flanks of the Dangyang basin. The Huangling massif, together with these basins on its two flanks, constitutes a nearly $\mathrm{N}-\mathrm{S}$ trending horst and graben system (Fig. 2 and Fig. 4).

Based on the lithology and geometry, the Huangling massif could be divided into three lithotectonic units (Fig. 2 and Fig. 4): (1) the migmatite, orthogneiss and metasupracrustal rocks of the Kongling complex, intruded by the Huangling granitoids; (2) the Neoproterozoic-Jurassic sedimentary cover, annularly surrounding the dome core; (3) the Cretaceous red-colored terrigeneous alluvial-fluvial deposits that occupy the graben or half-graben basins on the each flank of the dome. The stereographic plots of the structural elements in different units demonstrate their geometric relations (Fig. 5).

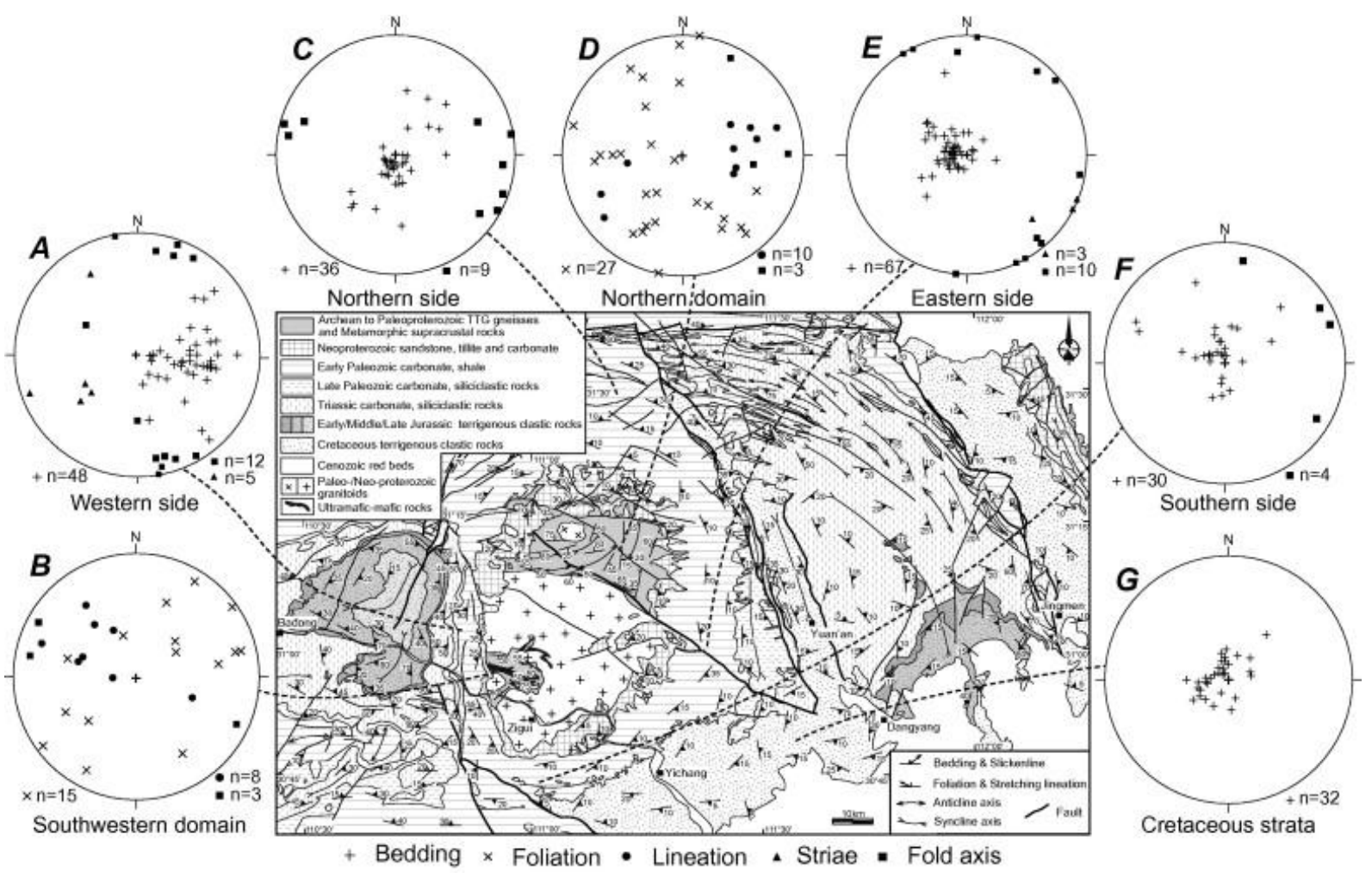

Fig. 5. : Structural planar and linear elements (bedding, fold axis, striae, foliation and lineation) of the Huangling massif. All diagrams are equal area projection, lower hemisphere.

In the northern domain of the Huangling massif, migmatite and gneiss constitute the main part of the basement. These rocks are strongly foliated even mylonitized with a well developed variably oriented foliation, and a consistent NEE-SWW striking mineral and stretching lineation (Fig. 5D). It is worthy to note that the foliation in the northern domain is folded with the axes around $\mathrm{E}-\mathrm{W}$ to $\mathrm{NE}-\mathrm{SW}$, and has no relation with the late deformation stages that are recorded in the sedimentary cover. On the southwestern part of the Huangling massif, to the north of the Zigui city, the exposed basement rocks consist of intensively foliated gneiss, amphibolite and serpentinite (Fig. 2). Even if the Huangling granitoids changed the geometry of this metamorphic basement, the systematic measurement of planar and linear structures shows a large SSW-verging syncline with steeply dipping foliation and WNW-ESE trending stretching lineation (Fig. 5B). All these deformed basement rocks were intruded by the undeformed Huangling granitoids, which indicate that this early ductile deformation occurred before ca. $820 \mathrm{Ma}$. 
The sedimentary cover around the Huangling massif dips to the periphery of the dome. On the western side of the massif, the Neoproterozoic-Jurassic strata dip to the west with moderate plunges $\left(20-60^{\circ}\right.$, maximum around $40^{\circ}$, Figs. $4 \mathrm{~A}, \mathrm{~B}$ and $\left.5 \mathrm{~A}\right)$; while on the eastern side, the Neoproterozoic-Triassic strata dip gently to the E or SEE with dip angles about $10-20^{\circ}$ (Figs. 4C, D and 5E). Similar to the eastern side of the massif, the attitudes of the NeoproterozoicSilurian strata in northern and southern sides are flat-lying, generally less than $15^{\circ}$, dipping to the north and to the south, respectively (Fig. 5C and F). The two depressions superimposed along the flanks of the Dangyang basin are mainly filled by Lower to Upper Cretaceous deposits. These beds are flat lying in the depression center and slightly tilted near the normal fault boundary (Fig. 5G). The Lower Cretaceous strata near the Yichang city dip gently to the southeast as a monocline (Fig. 5G).

\subsection{Deformation styles related to the uplifting of the Huangling massif}

According to our survey, the ductile deformation is limited to the Kongling complex (Fig. 2). Conversely to the previous work, there is neither detachment fault nor basal décollement layer between the metamorphic basement and the sedimentary cover, or the metamorphic rocks and the granitic intrusion (Jiang et al., 2002). Most of the deformation in the sedimentary cover is represented by folds observed in the different strata under shallow tectonic levels depending on the lithology (Fig. 4). The subsequent brittle normal faulting controlled the opening of the Cretaceous grabens and half-grabens on the dome flanks (Fig. 4B, C, and E).

\subsubsection{Deformation during the doming}

\subsubsection{Deformation on the western side of the Huangling massif}

Along the main road west from Zigui city, Neoproterozoic strata are represented by sandstone, limestone and dolomite (Fig. 3). Moderate to thin bedded limestone is deformed by $\mathrm{N}-\mathrm{S}$ trending, and west-verging meter-scale recumbent folds (Fig. 6A). More to the west, Cambrian limestone is strongly folded with a west-verging collapse style (Fig. 6B). Several meter-scale folds overturned to the west with the same deformation style are also observed in the Ordovician moderate-bedded limestone (Fig. 6C). In the Triassic thin-bedded limestone, meter-scale décollement-related folds and transverse bedding stylolites indicate a subvertical shortening (Fig. 6D). Calcite tension veins showing normal displacement can be observed in these folded strata. Overall, the Neoproterozoic, Cambrian, Ordovician and Triassic strata are deformed by $\mathrm{N}-\mathrm{S}$ trending, west-verging folds (Figs. 4A, B and 5A). These structures are related to the westward normal motion of the sedimentary cover along the western flank of the dome. 

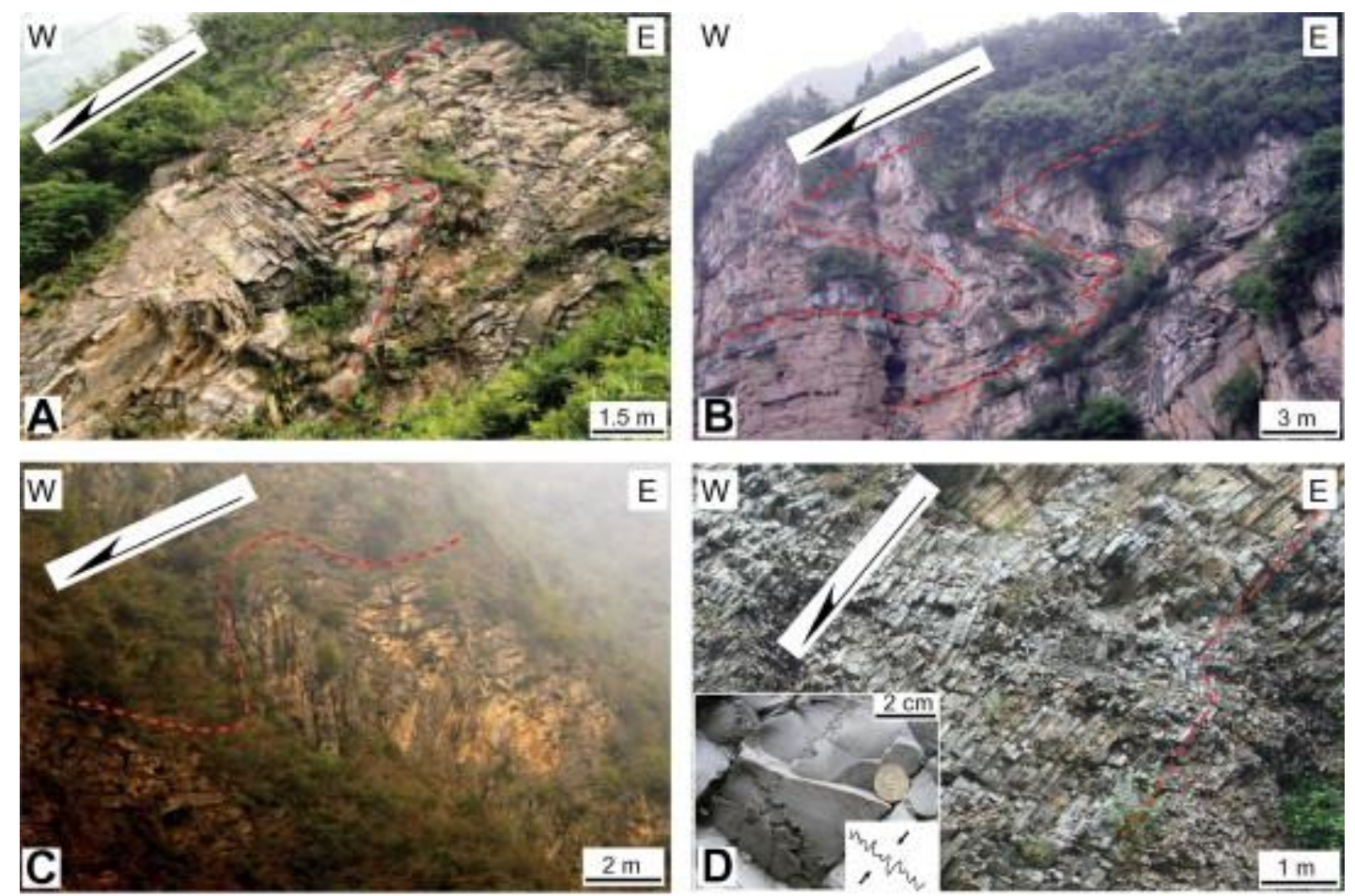

Fig. 6. : Field photographs showing the deformation on the western side of the Huanling massif. (A) Meter-scale recumbent fold overturned to the west in the Neoproterozoic limestone $\left(30^{\circ} 52.934^{\prime}, 110^{\circ} 52.689^{\prime}\right)$; (B) Decameter-scale recumbent fold overturned to the west in the Cambrian limestone $\left(30^{\circ} 53.035^{\prime}, 110^{\circ} 50.406^{\prime}\right)$; (C) Meter-scale recumbent fold overturned to the west in the Ordovician Moderate-bedded limestone $\left(31^{\circ} 08.888^{\prime}\right.$, $\left.110^{\circ} 50.600^{\prime}\right)$; (D) Meter-scale décollement-related west-verging fold in the Triassic thinbedded limestone $\left(31^{\circ} 06.905^{\prime}, 110^{\circ} 48.044^{\prime}\right)$. It is noted that the transverse bedding stylolites indicate a bedding-parallel shortening.

\subsubsection{Deformation on the eastern side of the Huangling massif}

As mentioned in the bulk architecture Section 3.1, on the eastern side of the dome, the strata dip gently eastward, and seem to be less deformed than the western side (Fig. 5E). In fact, similar structures are observed in the eastern side of the massif, but the deformation is relatively weaker than on another side (Fig. 4C and D). In the Cambrian thick-bedded limestone, meter-scale décollement-related east-verging folds are observed (Fig. 7A). Asymmetric strain fringes at the extremities of pelitic nodules in the Silurian shale show a top-to-the-E shearing (Fig. 7B). More to the east, meter-scale recumbent folds, overturned to the east with nearly $\mathrm{N}-\mathrm{S}$ axes, were developed in the Triassic thin-bedded limestone (Fig. 7C). Moreover, the east-dipping bedding planes bear SEE-directed (i.e. down-dip) striations formed by eastward slip on the layers (Fig. 5E). Tension gashes and offset markers also indicate this normal displacement. 

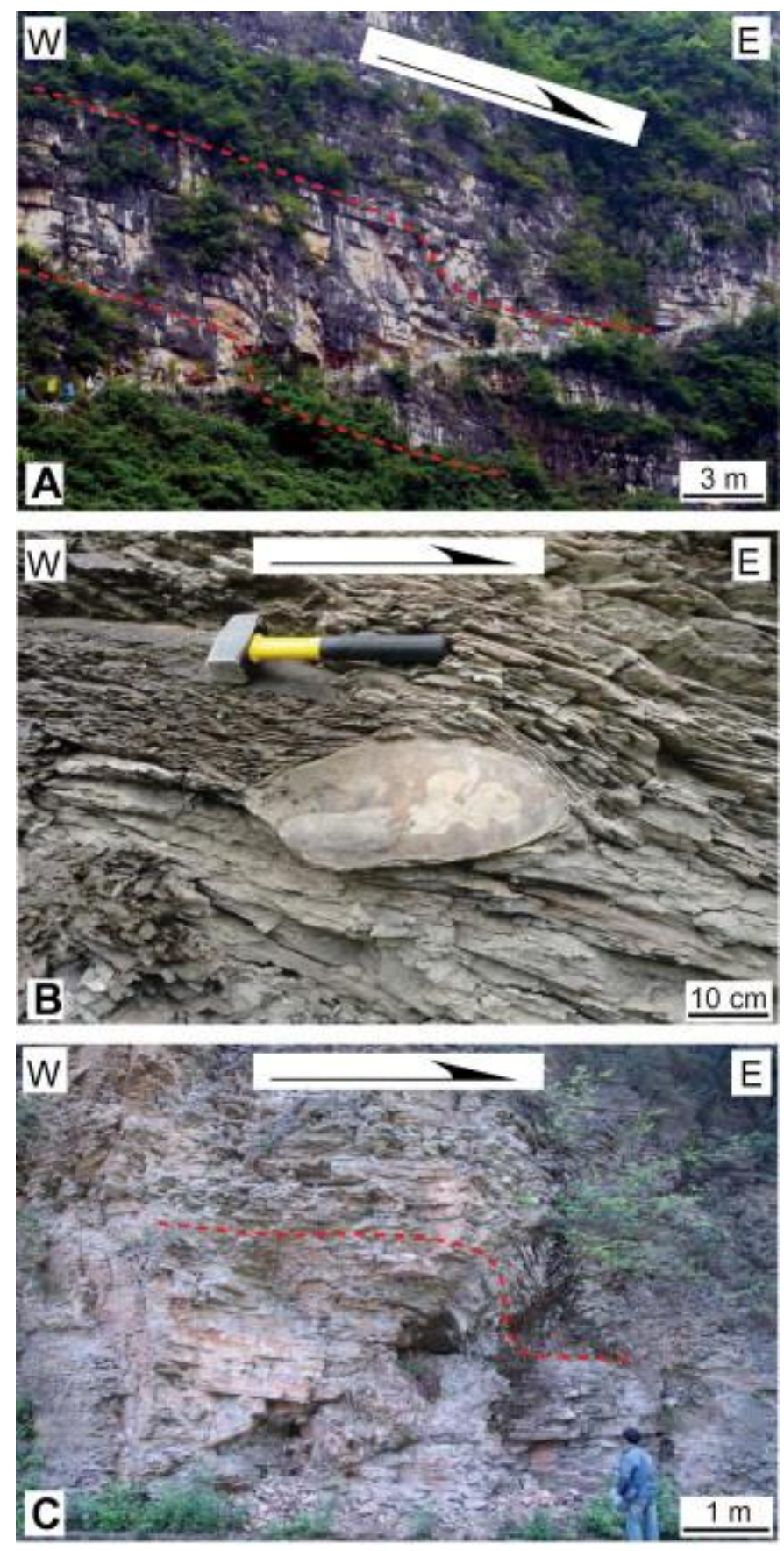

Fig. 7. : Field photographs showing the deformation on the eastern side of the Huanling massif. (A) Meter-scale décollement-related east-verging fold in the Cambrian limestone $\left(30^{\circ} 53.877^{\prime}, 111^{\circ} 20.598^{\prime}\right)$; (B) A pelitic nodule with strain fringes in the Silurian shale showing top-to-the-E shearing $\left(31^{\circ} 10.310^{\prime}, 111^{\circ} 25.803^{\prime}\right)$; (C) Meter-scale recumbent fold overturned to the east in the Triassic thin-bedded limestone $\left(31^{\circ} 11.065^{\prime}, 111^{\circ} 30.741^{\prime}\right)$.

To summarize, a series of recumbent folds developed on the western and eastern sides of the dome. These structures can be interpreted as gravity-driven collapse folds due to the folding of the tilted beds once they have reached the critical dip. Along the two sides of the dome, the fold axes strike dominantly $\mathrm{N}-\mathrm{S}$ with flat-lying axial planes, which indicate a vertical shortening accommodated to the uplifting of the massif. Therefore, these recumbent folds in the sedimentary cover are overturned to the west on the western side of the massif, and to the 
east on the eastern side, respectively. At the scale of the whole massif, we argue that they are nearly coeval and result from the same deformation mechanism. Such deformation features are widely developed in the Mesozoic extensional domes in eastern China, representing gravitational décollement and layer-parallel slip coeval with the doming (Faure et al., 1996, Faure et al., 1998, Faure et al., 2003, Lin et al., 2000 and Lin et al., 2013).

The Upper Jurassic siltstone and mudstone of the Zigui basin were involved in west limb of the dome. But the Lower Cretaceous coarse clastic deposits, totally about 2-km thick conglomerate on the southeast flank, overlie the deformed pre-Cretaceous strata with an angular unconformity (Fig 4). Therefore, the age of this deformation took place between the Late Jurassic and Early Cretaceous.

\subsubsection{Brittle normal faulting superposed on the Huangling massif}

To the east of the Huangling massif, the NNW-SSE trending Yuan'an graben and Jingmen half-graben are bounded by several normal faults (Figs. 2 and 4E). These high-angle boundary faults, about $60-80^{\circ}$, mainly cut the Cambrian-Triassic rocks and controlled the deposition of the Cretaceous alluvial-fluvial clastic rocks, forming an overall fining-upward sequence.

Tension gashes, Riedel fractures, offset markers, slickenlines and steps indicate predominantly normal displacement. Moreover, on the southwestern flank of the Huangling massif, an Early Cretaceous small half-graben unconformably covers the Paleozoic strata (Figs. 2 and 4B).

\section{Geochronological constraints}

\subsection{Previous geochronological data}

In the Huangling massif, several previous studies provided different time constraints. Abundant geochronological data, including $\mathrm{U}-\mathrm{Pb}, \mathrm{Rb}-\mathrm{Sr}$ and $\mathrm{Ar}-\mathrm{Ar}$, were concentrated on the Huangling granitoids (Fig. 8A). Zircon yields U-Pb ages of 794-837 Ma with a statistic peak around $810 \mathrm{Ma}$ (Fig. 8A, Ma et al., 1984, Feng et al., 1991, Li et al., 2002, Li et al., 2004, Ling et al., 2006, Zhang et al., 2008, S.B. Zhang et al., 2009 and Gao and Zhang, 2009). An average whole rock-mineral $\mathrm{Rb}-\mathrm{Sr}$ isochron age at $805 \pm 5 \mathrm{Ma}$ of diorite-quartz dioritetonalite complex probably represents the cooling age (Feng et al., 1991). ${ }^{40} \mathrm{Ar} /{ }^{39} \mathrm{Ar}$ dating of amphibole and biotite gave a relatively wide span of 770-900 Ma (Hu et al., 1989, Li et al., 2002 and $\mathrm{Li}$ et al., 2007). It is worthy to note that the $\mathrm{Rb}-\mathrm{Sr}$ and ${ }^{40} \mathrm{Ar} /{ }^{39} \mathrm{Ar}$ systems were not reset by Phanerozoic tectonic events. 


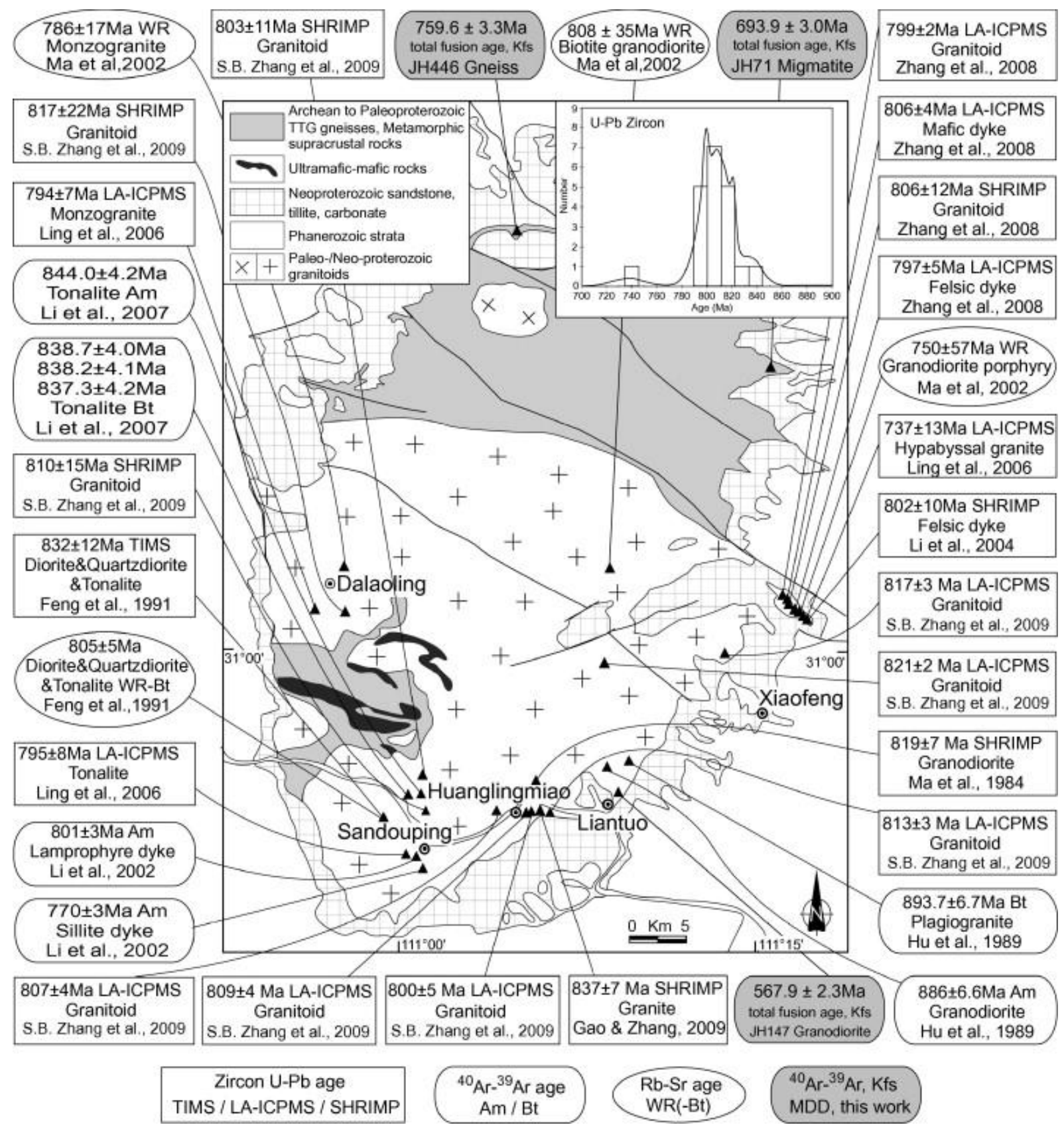

Fig. 8A. : Compilation of the $\mathrm{U}-\mathrm{Pb}, \mathrm{Rb}-\mathrm{Sr}$ and $\mathrm{Ar}-\mathrm{Ar}$ ages from the Huangling granitoids. Inset statistical chart shows the results of the zircon $\mathrm{U}-\mathrm{Pb}$ ages. Am, amphibole; Bt, biotote; Kfs, K-feldspar; WR(-Bt), Whole rock(-biotote).

Recently, in order to assess the uplifting time of the Huangling massif, an array of apatite and zircon fission-track (AFT, ZFT) and (U-Th)/He (AHe, ZHe) lower-temperature thermochronological data from the Huangling granitoids and Kongling complex were realized by several researchers (Fig. 8B, Hu et al., 2006, Hu et al., 2012, Shen et al., 2009, Richardson et al., 2010, Xu et al., 2010 and Li and Shan, 2011). The AFT ages range from 87 to $137 \mathrm{Ma}$ with a peak around $120 \mathrm{Ma}$. Three ZFT ages scatter at $158 \pm 50 \mathrm{Ma}, 178 \pm 34 \mathrm{Ma}$ and $195 \pm 14 \mathrm{Ma}$ with large error bars, which makes us difficult to take them into consideration. The AHe ages display a wide range from $39 \mathrm{Ma}$ to $102 \mathrm{Ma}$, but 
mainly concentrate on 40-45 Ma; ZHe ages distribute at a dispersive range of 121-309 Ma. Besides of these, Liu et al. (2009) presented nine AFT ages of 81-148 Ma from the Cambrian, Silurian, Jurassic and Cretaceous clastic rocks on the eastern flank of the Huangling massif.

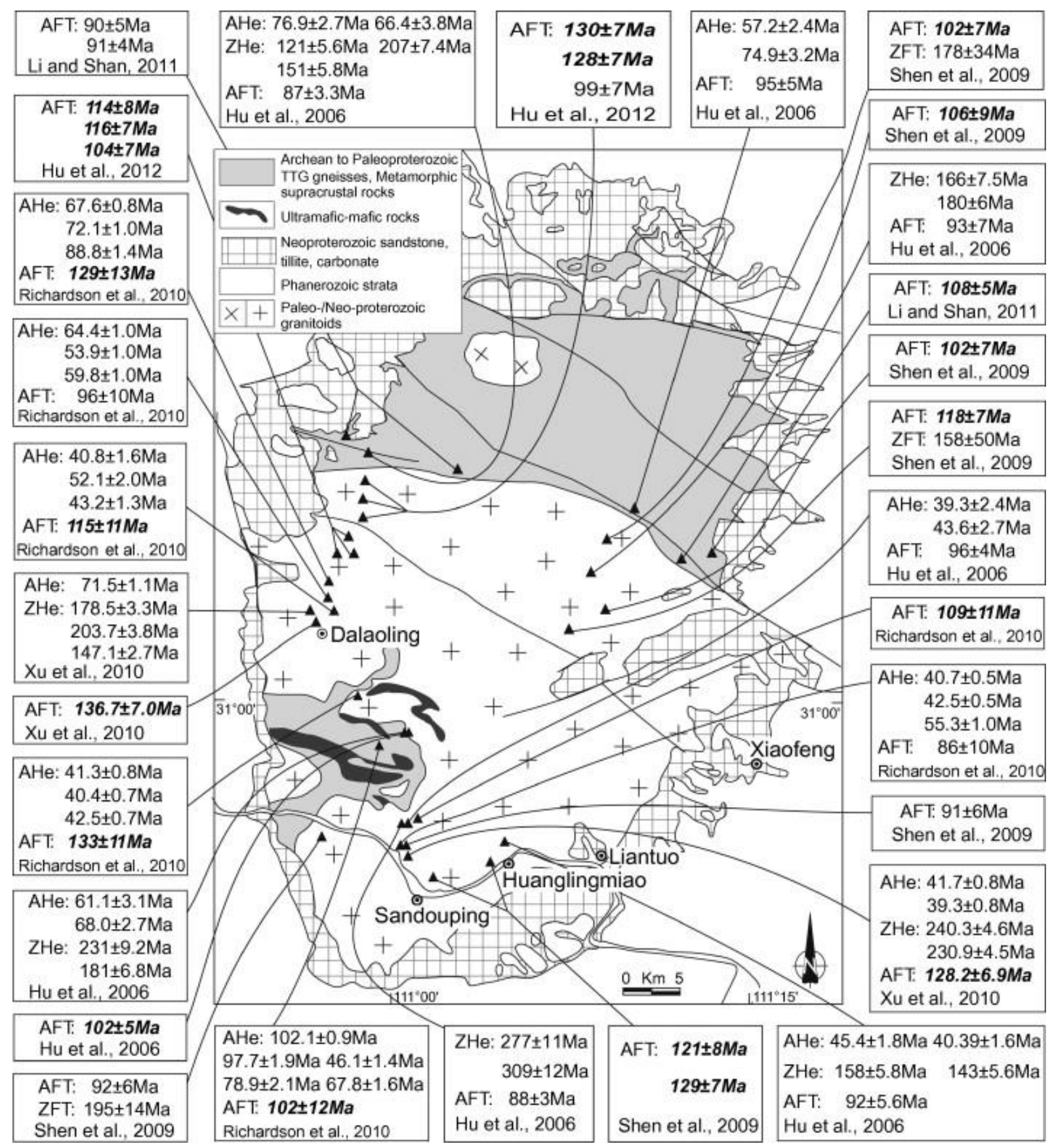

Fig. 8B. : Compilation of the apatite and zircon fission-track and (U-Th)/He ages from the Huangling massif. AHe, apatite (U-Th)/He; AFT, apatite-fission track; ZHe, zircon (U$\mathrm{Th}) / \mathrm{He}$; ZFT, zircon-fission track.

\section{2. ${ }^{40} \mathrm{Ar} /{ }^{39} \mathrm{Ar}$ analyses and MDD modeling}

Due to the lack of geochronological record during the 800-200 Ma period, we are unable to precisely depict the cooling and uplifting history of the Huangling massif in this long interval. In order to reveal more details of the tectono-thermal evolution history of the Huangling 
massif since Neoproterozoic, especially considering the core of the dome, three K-feldspar samples from the Kongling complex and Huangling granitoids had been analyzed by the ${ }^{40} \mathrm{Ar} /{ }^{39} \mathrm{Ar}$ incremental heating method (McDougall and Harrison, 1999) and modeled by the multi-domain diffusion (MDD) theory (Lovera et al., 1997 and Lovera et al., 2002).

Sample JH446 is a banded gneiss with clear alternating dark biotite-rich and light-colored quartzo-feldspathic bands in the field. This sample, belonging to the Kongling complex, was collected from the northernmost part of the dome core (Fig. 8A). It is composed of 25\% quartz, $45 \%$ plagioclase, $15 \% \mathrm{~K}$-feldspar and $15 \%$ biotite. Undulatory extinction is common in quartz ribbons. Biotite is euhedral to subhedral and shows yellow to brown pleochroism.

Sample JH71 is a foliated migmatite from the Kongling complex in the northern domain of the massif (Fig. 8A). The quartzo-feldspathic leucosomes are strongly folded, indicating partial melting during deformation. In thin section, JH71 was comprises about $25 \%$ quartz, $40 \%$ K-feldspar, $20 \%$ plagioclase, $10 \%$ biotite and 5\% hornblende. Quartz occurs as globular recrystallized subgrains with undulatory extinction. Microcline is the dominant K-feldspar. Much of the Plagioclase crystals were altered to sericite. Subhedral biotite and hornblende grains are locally replaced by chlorite.

Sample JH147 is an undeformed granodiorite from the southeastern part of the Huangling granitoids (Fig. 8A, near Liantuo village). On outcrop, the rock is leucocratic, medium- to coarse-grained, with K-feldspar as minor phenocrysts. It contains about 30\% quartz, 53\% plagioclase, $10 \% \mathrm{~K}$-feldspar, $5 \%$ biotite and $2 \%$ hornblende. Accessory minerals include magnetite, zircon and apatite. This granodiorite suite was dated at $819 \pm 7$ Ma by SHRIMP Zircon U-Pb method (Ma et al., 1984).

K-feldspars were obtained by the usual mineral separation techniques and finally handpicked under a binocular to remove all visible impurities. Aliquots of $\mathrm{K}$-feldspar were wrapped separately in aluminum foil to form wafers and stacked in quartz vial. The samples were irradiated at the B4 position in the 49-2 Reactor (China Institute of Atomic Energy, Beijing) for $36 \mathrm{~h}$. The ${ }^{40} \mathrm{Ar} /{ }^{39} \mathrm{Ar}$ analyses were performed in the Institute of Geology and Geophysics, Chinese Academy of Sciences. Detailed analytical procedures followed Wang et al. (2006). Samples were heated stepwise with a double vacuum resistance furnace. The released gas was purified with $\mathrm{Zr}-\mathrm{Al}$ getters. The isotopic composition was measured using a MM-5400 mass spectrometer. After corrections for mass discrimination, system blanks, radiometric interference, ${ }^{40} \mathrm{Ar} /{ }^{39} \mathrm{Ar}$ ages were calculated according to ${ }^{40} \mathrm{Ar}^{*} /{ }^{39} \mathrm{Ar}_{\mathrm{K}}$ ratios and $J$ value obtained by analyses of the monitors, as well as the decay constant. The correction factors herein are: $\left[{ }^{36} \mathrm{Ar} /{ }^{37} \mathrm{Ar}\right]_{\mathrm{Ca}}=0.000261,\left[{ }^{39} \mathrm{Ar} /{ }^{37} \mathrm{Ar}\right]_{\mathrm{Ca}}=0.000724$ and $\left[{ }^{40} \mathrm{Ar} /{ }^{39} \mathrm{Ar}\right]_{\mathrm{K}}=0.000880$. The data were processed using ArArCALC software (Koppers, 2002), and the apparent ages are reported at $2 \sigma$ uncertainties. The ${ }^{40} \mathrm{Ar} /{ }^{39} \mathrm{Ar}$ analytical data are listed in Table 1. After appropriate adjustment of the various model parameters, e.g. active energy, relative domain size, a modeled age spectrum and cooling history can be obtained by MDD modeling.

Table 1.

${ }^{40} \mathrm{Ar} /{ }^{39} \mathrm{Ar}$ analytical data on K-feldspars from the core of the Huangling massif.

$$
\begin{aligned}
& \text { Termperatur }{ }^{40} \mathrm{Ar} /{ }^{39} \mathrm{~A}{ }^{37} \mathrm{Ar} /{ }^{39} \mathrm{~A}{ }^{36} \mathrm{Ar} /{ }^{39} \mathrm{~A}{ }^{40} \mathrm{Ar} /{ }^{* 3} \mathrm{Ar} \quad{ }_{*}^{40} \mathrm{Ar}{ }^{39} \mathrm{Ar}
\end{aligned}
$$

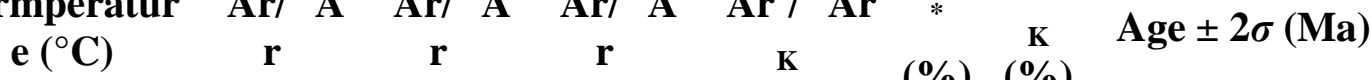

$$
\begin{aligned}
& \text { (\%) (\%) }
\end{aligned}
$$




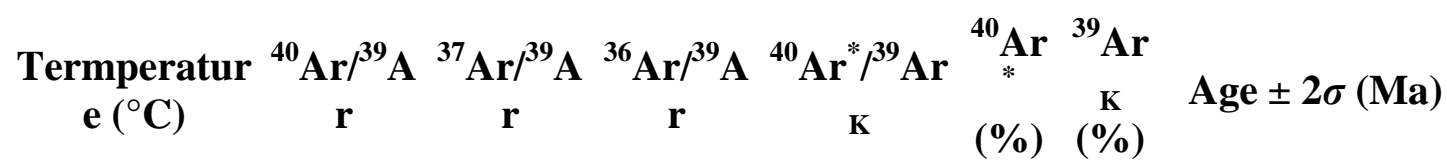

JH446, Gneiss, $K f$, weight $=12.3 \mathrm{mg}, J=0.005598$, total fusion

age $=759.6 \pm 3.3 \mathrm{Ma}$, GPS: $31^{\circ} 19.982^{\prime}, 111^{\circ} 05.738^{\prime}$

\begin{tabular}{|c|c|c|c|c|c|c|c|}
\hline 600 & 768.67 & 0.4641 & 2.1664 & 128.579 & $\begin{array}{l}16.7 \\
2\end{array}$ & 0.01 & $980.47 \pm 519.29$ \\
\hline 600 & 1523.39 & 1.1305 & 4.1970 & 283.584 & $\begin{array}{l}18.6 \\
0\end{array}$ & 0.00 & $\begin{array}{l}1719.16 \pm 1218.2 \\
5\end{array}$ \\
\hline 650 & 357.47 & 0.1683 & 0.9389 & 80.044 & $\begin{array}{l}22.3 \\
9\end{array}$ & 0.01 & $669.52 \pm 209.56$ \\
\hline 650 & 162.44 & 0.0618 & 0.4442 & 31.186 & $\begin{array}{l}19.2 \\
0\end{array}$ & 0.03 & $290.98 \pm 31.40$ \\
\hline 700 & 503.56 & 0.0106 & 1.5083 & 57.862 & $\begin{array}{l}11.4 \\
9\end{array}$ & 0.09 & $507.41 \pm 85.21$ \\
\hline 700 & 272.59 & 0.0014 & 0.7965 & 37.216 & $\begin{array}{l}13.6 \\
5\end{array}$ & 0.17 & $342.22 \pm 47.90$ \\
\hline 750 & 109.03 & 0.0047 & 0.2833 & 25.321 & $\begin{array}{l}23.2 \\
2\end{array}$ & 0.48 & $239.71 \pm 17.97$ \\
\hline 750 & 127.71 & 0.0038 & 0.3432 & 26.303 & $\begin{array}{l}20.6 \\
0\end{array}$ & 0.53 & $248.40 \pm 21.56$ \\
\hline 800 & 60.837 & 0.0039 & 0.1117 & 27.824 & $\begin{array}{l}45.7 \\
3\end{array}$ & 0.94 & $261.76 \pm 7.29$ \\
\hline 800 & 56.042 & 0.0037 & 0.0907 & 29.234 & $\begin{array}{l}52.1 \\
6\end{array}$ & 0.91 & $274.08 \pm 5.87$ \\
\hline 850 & 52.844 & 0.0049 & 0.0585 & 35.547 & $\begin{array}{l}67.2 \\
7\end{array}$ & 1.48 & $328.17 \pm 4.09$ \\
\hline 850 & 52.770 & 0.0024 & 0.0490 & 38.292 & $\begin{array}{l}72.5 \\
6\end{array}$ & 1.12 & $351.20 \pm 3.83$ \\
\hline 875 & 55.918 & 0.0038 & 0.0401 & 44.083 & $\begin{array}{l}78.8 \\
3\end{array}$ & 1.00 & $398.84 \pm 3.40$ \\
\hline 875 & 56.490 & 0.0035 & 0.0354 & 46.041 & $\begin{array}{l}81.5 \\
0\end{array}$ & 0.94 & $414.68 \pm 3.58$ \\
\hline 900 & 61.936 & 0.0063 & 0.0295 & 53.217 & $\begin{array}{l}85.9 \\
2\end{array}$ & 0.97 & $471.53 \pm 3.68$ \\
\hline 925 & 65.297 & 0.0052 & 0.0239 & 58.238 & $\begin{array}{l}89.1 \\
9\end{array}$ & 1.37 & $510.27 \pm 3.36$ \\
\hline 950 & 68.145 & 0.0060 & 0.0195 & 62.389 & $\begin{array}{l}91.5 \\
5\end{array}$ & 1.87 & $541.69 \pm 3.19$ \\
\hline 975 & 73.387 & 0.0055 & 0.0141 & 69.228 & $\begin{array}{l}94.3 \\
3\end{array}$ & 2.60 & $592.28 \pm 3.38$ \\
\hline 1000 & 79.840 & 0.0061 & 0.0120 & 76.290 & $\begin{array}{l}95.5 \\
5\end{array}$ & 2.68 & $643.08 \pm 3.51$ \\
\hline 1025 & 84.203 & 0.0044 & 0.0076 & 81.943 & $\begin{array}{l}97.3 \\
2\end{array}$ & 5.37 & $682.75 \pm 3.63$ \\
\hline
\end{tabular}




\begin{tabular}{|c|c|c|c|c|c|c|c|}
\hline $\begin{array}{l}\text { Termperatur } \\
\text { e }\left({ }^{\circ} \mathrm{C}\right)\end{array}$ & ${ }_{\mathbf{r}}^{{ }^{40} \mathrm{Ar} /{ }^{39} \mathrm{~A}}$ & ${ }_{\mathbf{r}}^{{ }^{37} \mathbf{A r}}{ }^{39} \mathbf{A}$ & ${ }_{\mathbf{r}}^{36} \mathrm{Ar} /{ }^{39} \mathrm{~A}$ & ${ }_{\mathrm{K}}^{40} \mathrm{Ar} /{ }^{39} \mathrm{Ar}$ & $\begin{array}{l}{ }_{*}^{40} \mathrm{Ar} \\
(\%)\end{array}$ & $\begin{array}{c}{ }^{39} \mathbf{A r} \\
\mathbf{K} \\
(\%)\end{array}$ & Age $\pm 2 \sigma(\mathrm{Ma})$ \\
\hline 1050 & 90.313 & 0.0033 & 0.0069 & 88.275 & $\begin{array}{l}97.7 \\
4\end{array}$ & 8.29 & $726.16 \pm 4.11$ \\
\hline 1075 & 91.238 & 0.0033 & 0.0064 & 89.361 & $\begin{array}{l}97.9 \\
4\end{array}$ & 7.39 & $733.50 \pm 3.79$ \\
\hline 1100 & 95.529 & 0.0030 & 0.0056 & 93.865 & $\begin{array}{l}98.2 \\
6\end{array}$ & 6.50 & $763.64 \pm 3.94$ \\
\hline 1100 & 98.871 & 0.0031 & 0.0054 & 97.286 & $\begin{array}{l}98.4 \\
0\end{array}$ & 5.74 & $786.20 \pm 4.00$ \\
\hline 1100 & 102.62 & 0.0027 & 0.0044 & 101.33 & $\begin{array}{l}98.7 \\
5\end{array}$ & 4.07 & $812.52 \pm 4.04$ \\
\hline 1100 & 105.84 & 0.0021 & 0.0032 & 104.88 & $\begin{array}{l}99.1 \\
0\end{array}$ & 4.36 & $835.33 \pm 4.20$ \\
\hline 1100 & 109.08 & 0.0012 & 0.0023 & 108.41 & $\begin{array}{l}99.3 \\
9\end{array}$ & 3.57 & $857.67 \pm 4.32$ \\
\hline 1100 & 112.91 & 0.0010 & 0.0025 & 112.18 & $\begin{array}{l}99.3 \\
6\end{array}$ & 4.94 & $881.26 \pm 4.33$ \\
\hline 1100 & 116.02 & 0.0006 & 0.0033 & 115.05 & $\begin{array}{l}99.1 \\
6\end{array}$ & 6.30 & $899.00 \pm 4.39$ \\
\hline 1200 & 115.29 & 0.0011 & 0.0019 & 114.72 & $\begin{array}{l}99.5 \\
1\end{array}$ & 3.20 & $897.01 \pm 4.44$ \\
\hline 1225 & 111.03 & 0.0012 & 0.0019 & 110.47 & $\begin{array}{l}99.4 \\
9\end{array}$ & 5.62 & $870.61 \pm 4.28$ \\
\hline 1250 & 108.98 & 0.0007 & 0.0020 & 108.40 & $\begin{array}{l}99.4 \\
7\end{array}$ & 7.28 & $857.63 \pm 4.17$ \\
\hline 1300 & 109.13 & 0.0006 & 0.0020 & 108.55 & $\begin{array}{l}99.4 \\
7\end{array}$ & 8.23 & $858.54 \pm 5.41$ \\
\hline 1350 & 109.01 & 0.0012 & 0.0030 & 108.11 & $\begin{array}{l}99.1 \\
7\end{array}$ & 0.95 & $855.76 \pm 4.75$ \\
\hline 1400 & 114.00 & 0.0048 & 0.0068 & 112.00 & $\begin{array}{l}98.2 \\
5\end{array}$ & 0.23 & $880.16 \pm 7.46$ \\
\hline 1500 & 111.38 & 0.0005 & 0.0073 & 109.21 & $\begin{array}{l}98.0 \\
5\end{array}$ & 0.73 & $862.73 \pm 5.46$ \\
\hline \multicolumn{8}{|c|}{$\begin{array}{l}\text { JH71, Migmatite, } K f \text { s, weight }=14.6 \mathrm{mg}, \mathrm{J}=0.005717, \text { total fusion } \\
\text { age }=693.9 \pm 3.0 \mathrm{Ma}, \mathrm{GPS}: 31^{\circ} 12.906^{\prime}, 111^{\circ} 16.829^{\prime}\end{array}$} \\
\hline 600 & 587.80 & 0.5444 & 1.8277 & 47.786 & 8.13 & 0.00 & $436.76 \pm 163.72$ \\
\hline 600 & 134.25 & 0.4680 & 0.3947 & 17.667 & $\begin{array}{l}13.1 \\
5\end{array}$ & 0.01 & $174.00 \pm 40.06$ \\
\hline 650 & 111.13 & 0.1092 & 0.3269 & 14.546 & $\begin{array}{l}13.0 \\
9\end{array}$ & 0.02 & $144.45 \pm 33.44$ \\
\hline 650 & 97.84 & 0.0451 & 0.2804 & 14.973 & $\begin{array}{l}15.3 \\
0\end{array}$ & 0.05 & $148.52 \pm 32.28$ \\
\hline 700 & 277.26 & 0.0076 & 0.8592 & 23.367 & 8.43 & 0.12 & $226.74 \pm 55.92$ \\
\hline
\end{tabular}




\begin{tabular}{|c|c|c|c|c|c|c|c|}
\hline $\begin{array}{l}\text { Termperatur } \\
\text { e }\left({ }^{\circ} \mathbf{C}\right)\end{array}$ & $\begin{array}{c}{ }^{40} \mathrm{Ar} /{ }^{39} \mathrm{~A} \\
\end{array}$ & $\begin{array}{c}{ }^{37} \mathbf{A r} /{ }^{39} \mathbf{A} \\
\mathbf{r}\end{array}$ & $\begin{array}{c}{ }^{36} \mathrm{Ar} /{ }^{39} \mathrm{~A} \\
\mathbf{r}\end{array}$ & $\begin{array}{c}{ }^{40} \mathrm{Ar}{ }^{*} /{ }^{39} \mathrm{Ar} \\
\end{array}$ & $\begin{array}{l}{ }_{*}^{40} \mathbf{A r} \\
(\%)\end{array}$ & $\begin{array}{c}{ }^{39} \mathbf{A r} \\
\mathbf{K} \\
(\%)\end{array}$ & Age $\pm 2 \sigma(\mathrm{Ma})$ \\
\hline 700 & 179.64 & 0.0177 & 0.5357 & 21.345 & $\begin{array}{l}11.8 \\
8\end{array}$ & 0.17 & $208.21 \pm 35.21$ \\
\hline 750 & 75.271 & 0.0069 & 0.1972 & 16.998 & $\begin{array}{l}22.5 \\
8\end{array}$ & 0.47 & $167.70 \pm 13.25$ \\
\hline 750 & 50.819 & 0.0059 & 0.1052 & 19.725 & $\begin{array}{l}38.8 \\
1\end{array}$ & 0.55 & $193.22 \pm 7.22$ \\
\hline 800 & 40.757 & 0.0042 & 0.0496 & 26.093 & $\begin{array}{l}64.0 \\
2\end{array}$ & 1.02 & $251.44 \pm 3.61$ \\
\hline 800 & 47.777 & 0.0060 & 0.0443 & 34.682 & $\begin{array}{l}72.5 \\
9\end{array}$ & 0.75 & $327.10 \pm 3.64$ \\
\hline 850 & 57.516 & 0.0142 & 0.0440 & 44.523 & $\begin{array}{l}77.4 \\
1\end{array}$ & 0.96 & $410.07 \pm 3.65$ \\
\hline 850 & 67.090 & 0.0181 & 0.0459 & 53.521 & $\begin{array}{l}79.7 \\
7\end{array}$ & 0.72 & $482.74 \pm 4.03$ \\
\hline 875 & 72.315 & 0.0167 & 0.0428 & 59.658 & $\begin{array}{l}82.5 \\
0\end{array}$ & 0.68 & $530.68 \pm 5.18$ \\
\hline 900 & 72.476 & 0.0161 & 0.0217 & 66.075 & $\begin{array}{l}91.1 \\
7\end{array}$ & 0.93 & $579.48 \pm 3.84$ \\
\hline 925 & 73.113 & 0.0113 & 0.0153 & 68.587 & $\begin{array}{l}93.8 \\
1\end{array}$ & 1.52 & $598.23 \pm 3.51$ \\
\hline 950 & 73.372 & 0.0095 & 0.0088 & 70.764 & $\begin{array}{l}96.4 \\
4\end{array}$ & 1.87 & $614.33 \pm 3.38$ \\
\hline 975 & 75.568 & 0.0082 & 0.0079 & 73.247 & $\begin{array}{l}96.9 \\
3\end{array}$ & 2.65 & $632.51 \pm 3.37$ \\
\hline 1000 & 77.136 & 0.0044 & 0.0058 & 75.409 & $\begin{array}{l}97.7 \\
6\end{array}$ & 4.02 & $648.20 \pm 3.51$ \\
\hline 1025 & 78.652 & 0.0066 & 0.0039 & 77.502 & $\begin{array}{l}98.5 \\
4\end{array}$ & 6.99 & $663.25 \pm 3.48$ \\
\hline 1050 & 81.314 & 0.0045 & 0.0027 & 80.509 & $\begin{array}{l}99.0 \\
1\end{array}$ & $\begin{array}{l}10.3 \\
3\end{array}$ & $684.67 \pm 3.55$ \\
\hline 1075 & 84.073 & 0.0028 & 0.0023 & 83.390 & $\begin{array}{l}99.1 \\
9\end{array}$ & 8.37 & $704.95 \pm 3.68$ \\
\hline 1100 & 84.930 & 0.0025 & 0.0019 & 84.367 & $\begin{array}{l}99.3 \\
4\end{array}$ & 6.45 & $711.78 \pm 3.73$ \\
\hline 1100 & 86.684 & 0.0017 & 0.0011 & 86.372 & $\begin{array}{l}99.6 \\
4\end{array}$ & 6.80 & $725.71 \pm 3.67$ \\
\hline 1100 & 88.732 & 0.0013 & 0.0013 & 88.352 & $\begin{array}{l}99.5 \\
7\end{array}$ & 5.43 & $739.36 \pm 3.79$ \\
\hline 1100 & 89.998 & 0.0010 & 0.0017 & 89.501 & $\begin{array}{l}99.4 \\
5\end{array}$ & 6.88 & $747.23 \pm 3.79$ \\
\hline 1100 & 90.829 & 0.0007 & 0.0021 & 90.204 & $\begin{array}{l}99.3 \\
1\end{array}$ & 5.10 & $752.03 \pm 3.82$ \\
\hline
\end{tabular}




\begin{tabular}{|c|c|c|c|c|c|c|c|}
\hline $\begin{array}{c}\text { Termperatur } \\
\text { e }\left({ }^{\circ} \mathbf{C}\right)\end{array}$ & ${ }_{\mathrm{r}}^{{ }^{40} \mathrm{Ar} /{ }^{39} \mathrm{~A}}$ & ${ }_{\mathbf{r}}^{{ }^{37} \mathbf{A r} /{ }^{39} \mathrm{~A}}$ & ${ }_{\mathrm{r}}^{{ }^{36} \mathrm{Ar} /{ }^{39} \mathrm{~A}}$ & ${ }_{\mathrm{K}}^{{ }^{40} \mathrm{Ar}}{ }^{*} /{ }^{39} \mathrm{Ar}$ & $\begin{array}{l}{ }_{*}^{40} \mathrm{Ar} \\
(\%)\end{array}$ & $\begin{array}{c}{ }^{39} \mathrm{Ar} \\
\mathbf{K} \\
(\%)\end{array}$ & Age $\pm 2 \sigma(\mathrm{Ma})$ \\
\hline 1100 & 89.342 & 0.0009 & 0.0015 & 88.896 & $\begin{array}{l}99.5 \\
0\end{array}$ & 9.42 & $743.09 \pm 3.73$ \\
\hline 1100 & 90.075 & 0.0006 & 0.0025 & 89.322 & $\begin{array}{l}99.1 \\
6\end{array}$ & 8.49 & $746.01 \pm 3.77$ \\
\hline 1150 & 89.940 & 0.0073 & 0.0009 & 89.678 & $\begin{array}{l}99.7 \\
1\end{array}$ & 0.40 & $748.44 \pm 5.46$ \\
\hline 1200 & 90.277 & 0.0024 & 0.0005 & 90.127 & $\begin{array}{l}99.8 \\
3\end{array}$ & 1.54 & $751.51 \pm 4.20$ \\
\hline 1225 & 89.995 & 0.0008 & 0.0008 & 89.745 & $\begin{array}{l}99.7 \\
2\end{array}$ & 2.32 & $748.90 \pm 3.99$ \\
\hline 1250 & 90.024 & 0.0009 & 0.0011 & 89.691 & $\begin{array}{l}99.6 \\
3\end{array}$ & 2.97 & $748.53 \pm 3.89$ \\
\hline 1275 & 91.409 & 0.0021 & 0.0034 & 90.398 & $\begin{array}{l}98.8 \\
9\end{array}$ & 1.45 & $753.36 \pm 4.45$ \\
\hline 1300 & 93.721 & 0.0069 & 0.0066 & 91.758 & $\begin{array}{l}97.9 \\
0\end{array}$ & 0.36 & $762.60 \pm 4.96$ \\
\hline 1350 & 91.364 & 0.0311 & 0.0110 & 88.115 & $\begin{array}{l}96.4 \\
4\end{array}$ & 0.09 & $737.73 \pm 23.13$ \\
\hline 1400 & 88.350 & 0.0148 & 0.0091 & 85.672 & $\begin{array}{l}96.9 \\
7\end{array}$ & 0.09 & $720.86 \pm 17.36$ \\
\hline
\end{tabular}

JH147, Granodiorite, $K f s$, weight $=15.1 \mathrm{mg}, J=0.005695$, total fusion age $=567.9 \pm 2.3 \mathrm{Ma}$, GPS: $30^{\circ} 51.400^{\prime}, 111^{\circ} 08.917^{\prime}$

\begin{tabular}{|c|c|c|c|c|c|c|c|}
\hline 600 & 461.75 & 0.6943 & 1.2474 & 93.257 & $\begin{array}{l}20.1 \\
8\end{array}$ & 0.00 & $770.32 \pm 295.10$ \\
\hline 600 & 554.33 & 1.0998 & 1.4793 & 117.393 & $\begin{array}{l}21.1 \\
6\end{array}$ & 0.00 & $925.78 \pm 604.47$ \\
\hline 650 & 96.69 & 0.0778 & 0.2434 & 24.784 & $\begin{array}{l}25.6 \\
3\end{array}$ & 0.04 & $238.76 \pm 35.30$ \\
\hline 650 & 117.33 & 0.0434 & 0.3030 & 27.791 & $\begin{array}{l}23.6 \\
8\end{array}$ & 0.05 & $265.69 \pm 26.15$ \\
\hline 700 & 244.30 & 0.0258 & 0.7078 & 35.143 & $\begin{array}{l}14.3 \\
8\end{array}$ & 0.18 & $329.90 \pm 43.28$ \\
\hline 700 & 118.29 & 0.0239 & 0.3046 & 28.274 & $\begin{array}{l}23.9 \\
0\end{array}$ & 0.28 & $269.98 \pm 19.42$ \\
\hline 750 & 56.791 & 0.0436 & 0.1061 & 25.450 & $\begin{array}{l}44.8 \\
1\end{array}$ & 0.76 & $244.76 \pm 7.03$ \\
\hline 750 & 46.785 & 0.0139 & 0.0599 & 29.075 & $\begin{array}{l}62.1 \\
5\end{array}$ & 0.90 & $277.07 \pm 4.26$ \\
\hline 800 & 46.183 & 0.0220 & 0.0286 & 37.729 & $\begin{array}{l}81.6 \\
9\end{array}$ & 1.66 & $351.96 \pm 3.09$ \\
\hline 800 & 52.011 & 0.0129 & 0.0317 & 42.658 & $\begin{array}{l}82.0 \\
2\end{array}$ & 1.33 & $393.27 \pm 3.01$ \\
\hline
\end{tabular}




\begin{tabular}{|c|c|c|c|c|c|c|c|}
\hline $\begin{array}{c}\text { Termperatur } \\
\text { e }\left({ }^{\circ} \mathbf{C}\right)\end{array}$ & $\begin{array}{c}{ }^{40} \mathrm{Ar} /{ }^{39} \mathrm{~A} \\
\end{array}$ & $\begin{array}{c}{ }^{37} \mathbf{A r} /{ }^{39} \mathbf{A} \\
\mathbf{r}\end{array}$ & ${ }^{{ }^{36} \mathrm{Ar} /{ }^{39} \mathrm{~A}}$ & ${ }_{\mathrm{K}}^{{ }^{40} \mathrm{Ar}}{ }^{*} /{ }^{39} \mathrm{Ar}$ & $\begin{array}{l}{ }_{*}^{40} \mathbf{A r} \\
(\%)\end{array}$ & $\begin{array}{c}{ }^{39} \mathbf{A r} \\
\mathbf{K} \\
(\%)\end{array}$ & Age $\pm 2 \sigma(\mathrm{Ma})$ \\
\hline 850 & 57.718 & 0.0205 & 0.0268 & 49.798 & $\begin{array}{l}86.2 \\
8\end{array}$ & 1.72 & $451.48 \pm 3.11$ \\
\hline 850 & 64.802 & 0.0140 & 0.0292 & 56.164 & $\begin{array}{l}86.6 \\
7\end{array}$ & 1.12 & $501.85 \pm 3.52$ \\
\hline 875 & 70.111 & 0.0156 & 0.0341 & 60.039 & $\begin{array}{l}85.6 \\
3\end{array}$ & 0.82 & $531.83 \pm 3.82$ \\
\hline 875 & 72.133 & 0.0132 & 0.0332 & 62.323 & $\begin{array}{l}86.4 \\
0\end{array}$ & 0.68 & $549.27 \pm 3.95$ \\
\hline 900 & 70.752 & 0.0135 & 0.0276 & 62.590 & $\begin{array}{l}88.4 \\
6\end{array}$ & 0.56 & $551.30 \pm 5.01$ \\
\hline 925 & 74.189 & 0.0176 & 0.0385 & 62.810 & $\begin{array}{l}84.6 \\
6\end{array}$ & 0.72 & $552.97 \pm 4.04$ \\
\hline 950 & 72.025 & 0.0152 & 0.0358 & 61.457 & $\begin{array}{l}85.3 \\
3\end{array}$ & 0.87 & $542.68 \pm 3.84$ \\
\hline 975 & 69.663 & 0.0178 & 0.0289 & 61.117 & $\begin{array}{l}87.7 \\
3\end{array}$ & 1.04 & $540.08 \pm 3.67$ \\
\hline 1000 & 67.460 & 0.0160 & 0.0241 & 60.340 & $\begin{array}{l}89.4 \\
4\end{array}$ & 1.46 & $534.14 \pm 3.44$ \\
\hline 1025 & 65.818 & 0.0134 & 0.0173 & 60.700 & $\begin{array}{l}92.2 \\
2\end{array}$ & 2.69 & $536.90 \pm 3.06$ \\
\hline 1050 & 67.629 & 0.0121 & 0.0108 & 64.445 & $\begin{array}{l}95.2 \\
9\end{array}$ & 4.88 & $565.33 \pm 3.09$ \\
\hline 1075 & 66.573 & 0.0147 & 0.0101 & 63.592 & $\begin{array}{l}95.5 \\
2\end{array}$ & 3.55 & $558.89 \pm 3.12$ \\
\hline 1100 & 65.527 & 0.0134 & 0.0075 & 63.309 & $\begin{array}{l}96.6 \\
1\end{array}$ & 3.83 & $556.76 \pm 3.02$ \\
\hline 1100 & 66.360 & 0.0115 & 0.0062 & 64.531 & $\begin{array}{l}97.2 \\
4\end{array}$ & 4.84 & $565.98 \pm 3.12$ \\
\hline 1100 & 67.118 & 0.0095 & 0.0050 & 65.637 & $\begin{array}{l}97.7 \\
9\end{array}$ & 4.57 & $574.29 \pm 3.05$ \\
\hline 1100 & 67.725 & 0.0080 & 0.0053 & 66.157 & $\begin{array}{l}97.6 \\
8\end{array}$ & 5.60 & $578.18 \pm 3.11$ \\
\hline 1100 & 67.692 & 0.0066 & 0.0044 & 66.399 & $\begin{array}{l}98.0 \\
9\end{array}$ & 4.36 & $580.00 \pm 3.19$ \\
\hline 1100 & 69.194 & 0.0055 & 0.0039 & 68.037 & $\begin{array}{l}98.3 \\
3\end{array}$ & 6.16 & $592.19 \pm 3.16$ \\
\hline 1100 & 70.568 & 0.0045 & 0.0037 & 69.473 & $\begin{array}{l}98.4 \\
5\end{array}$ & 8.63 & $602.82 \pm 3.24$ \\
\hline 1150 & 70.073 & 0.0070 & 0.0033 & 69.107 & $\begin{array}{l}98.6 \\
2\end{array}$ & 0.64 & $600.12 \pm 3.81$ \\
\hline 1200 & 67.938 & 0.0075 & 0.0036 & 66.876 & $\begin{array}{l}98.4 \\
3\end{array}$ & 3.14 & $583.55 \pm 3.18$ \\
\hline
\end{tabular}




\begin{tabular}{|c|c|c|c|c|c|c|c|}
\hline $\begin{array}{c}\text { Termperatur } \\
\text { e }\left({ }^{\circ} \mathbf{C}\right)\end{array}$ & ${ }_{\mathrm{r}}^{{ }^{40} \mathrm{Ar} /{ }^{39} \mathrm{~A}}$ & $\underset{\mathbf{r}}{{ }^{37} \mathrm{Ar} /{ }^{39} \mathrm{~A}}$ & $\underset{r}{{ }^{36} \mathrm{Ar} /{ }^{39} \mathrm{~A}}$ & ${ }_{\mathrm{K}}^{{ }^{40} \mathrm{Ar}{ }^{*}{ }^{39} \mathrm{Ar}}$ & $\begin{array}{l}{ }_{*}^{40} \mathrm{Ar} \\
(\%)\end{array}$ & $\begin{array}{l}{ }^{39} \mathrm{Ar} \\
\mathbf{K} \\
(\%)\end{array}$ & Age $\pm 2 \sigma(\mathrm{Ma})$ \\
\hline 1225 & 69.179 & 0.0042 & 0.0032 & 68.226 & $\begin{array}{l}98.6 \\
2\end{array}$ & 6.11 & $593.60 \pm 3.19$ \\
\hline 1250 & 70.142 & 0.0021 & 0.0028 & 69.303 & $\begin{array}{l}98.8 \\
0\end{array}$ & $\begin{array}{l}12.0 \\
1\end{array}$ & $601.57 \pm 3.11$ \\
\hline 1275 & 70.434 & 0.0021 & 0.0030 & 69.548 & $\begin{array}{l}98.7 \\
4\end{array}$ & $\begin{array}{l}10.9 \\
9\end{array}$ & $603.37 \pm 4.14$ \\
\hline 1300 & 71.713 & 0.0029 & 0.0039 & 70.549 & $\begin{array}{l}98.3 \\
8\end{array}$ & 2.89 & $610.74 \pm 3.27$ \\
\hline 1350 & 71.131 & 0.0041 & 0.0050 & 69.642 & $\begin{array}{l}97.9 \\
1\end{array}$ & 0.49 & $604.07 \pm 3.90$ \\
\hline 1400 & 66.496 & 0.0157 & 0.0084 & 64.009 & $\begin{array}{l}96.2 \\
6\end{array}$ & 0.18 & $562.05 \pm 12.59$ \\
\hline 1500 & 71.522 & 0.0042 & 0.0104 & 68.445 & $\begin{array}{l}95.7 \\
0\end{array}$ & 0.23 & $595.22 \pm 6.01$ \\
\hline
\end{tabular}

The age spectra and modeling results are shown in Fig. 9. The abnormally old ages of the first steps are possibly due to the excess Ar present in the margin of the mineral. Subsequent increasing age pattern of K-feldspar may record its cooling history. Apparent ages of the three samples range from 239.7 to $899.0 \mathrm{Ma}(\mathrm{JH} 446$, total fusion ages $=759.6 \pm 3.3 \mathrm{Ma}$ ), 167.7 to $762.6 \mathrm{Ma}(\mathrm{JH} 71$, total fusion ages $=693.9 \pm 3.0 \mathrm{Ma})$ and 244.8 to $610.7 \mathrm{Ma}(\mathrm{JH} 147$, total fusion ages $=567.9 \pm 2.3 \mathrm{Ma}$ ), respectively. The modeled age spectra closely match the experimental results show that the qualities of the K-feldspar MDD modeling results are high (Fig. 9). Considering the closure temperature of K-feldspar, the cooling history between $350{ }^{\circ} \mathrm{C}$ and $150{ }^{\circ} \mathrm{C}$ is reliable. The K-feldspar MDD modeling result from JH446 gneiss shows a slow cooling before $450 \mathrm{Ma}$, then an obvious cooling event around $400 \mathrm{Ma}$ (Fig. 9). Except for the asynchronous cooling in early stage, JH71 migmatite and JH147 granodiorite reveal a long-term thermal stability period during Paleozoic, and a final cooling event since Late Triassic (Fig. 9). 

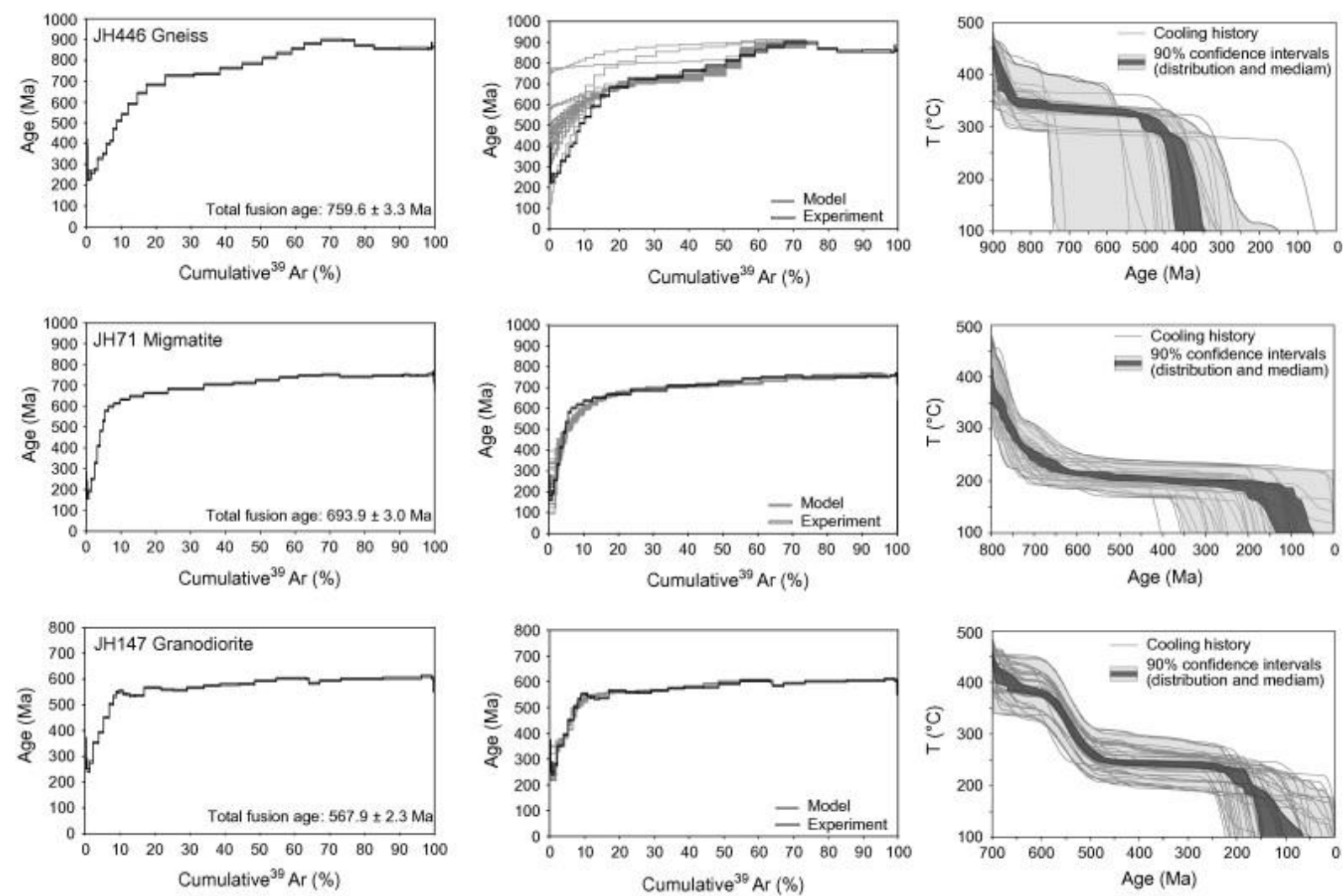

Fig. 9. : ${ }^{40} \mathrm{Ar}-{ }^{39} \mathrm{Ar}$ age spectra and the multi-domain diffusion (MDD) modeling results of Kfeldspar from different rock types in the core of Huangling massif.

\section{Discussion}

\subsection{Cooling and uplifting history of the Huangling massif}

The Huangling massif witnessed the tectonic evolution of SCB. In fact, the stratigraphic column recorded several tectonic events that occurred in the Neoproterozoic, Early Paleozoic, Early Mesozoic and Late Mesozoic times (Fig. 3). The combination of the stratigraphic relationships and the thermochronological data allows us to construct a synthetic temperaturetime curve, and to unravel the tectono-thermal history of the Huangling massif since the Neoproterozoic (Fig. 10A). 


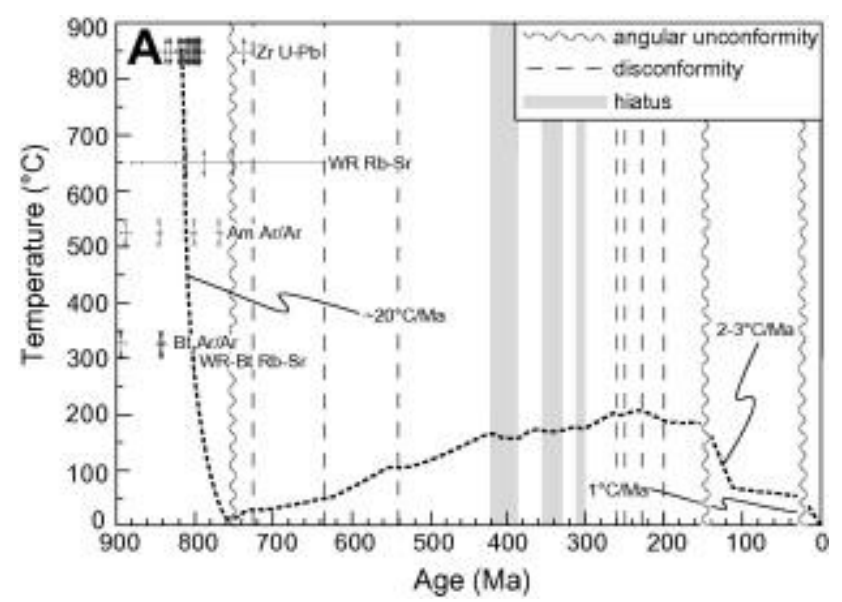

Fig. 10A. : A synthetic curve showing the tectono-thermal history of the Huangling massif with emphasis on the dome core. $\mathrm{Zr} \mathrm{U}-\mathrm{Pb}$, WR Rb-Sr, Am Ar-Ar, Bt Ar-Ar, WR-Bt Rb-Sr ages (Fig. 8A) are plotted at their closure temperatures of $850{ }^{\circ} \mathrm{C}, 650{ }^{\circ} \mathrm{C}, 525{ }^{\circ} \mathrm{C}, 325^{\circ} \mathrm{C}$ and $300{ }^{\circ} \mathrm{C}$, respectively.

The Kongling complex was intruded by the Huangling granitoids, and then unconformably overlain by the terrigeneous fluvial conglomerate at the base of the Neoproterozoic Liantuo Formation (Fig. 3). Available geochronological data reveal that the Huangling granitoids emplaced around 820-800 Ma, and then experienced a cooling from the closure temperature of Zircon U-Pb system to mineral Rb-Sr and K-Ar system before $770 \mathrm{Ma}$ (Fig. 10A). The $\mathrm{U}-\mathrm{Pb}$ ages of the youngest zircons from the Neoproterozoic Liantuo Formation indicate that its deposition time is no later than $750 \mathrm{Ma}$ (Zhang et al., 2006c and Liu et al., 2008), which agree with the age of $748 \pm 12 \mathrm{Ma}$ from the interlayer tuff in the lower part of the Liantuo Formation (Ma et al., 1984). Our K-feldspar MDD modeling results also show differential cooling processes during the Neoproterozoic (Fig. 9). The above evidence indicates that the Huangling massif was once exposed to the surface before $750 \mathrm{Ma}$. An approximately $20{ }^{\circ} \mathrm{C} / \mathrm{Ma}$ cooling rate can be inferred from the cooling curve (Fig. 10A).

The MDD modeling result from the gneiss (JH446) presents a distinct cooling event around $400 \mathrm{Ma}$ (Fig. 9). It appears that the Huangling massif locally suffered a weak thermal disturbance during Silurian to Devonian. From the view of whole SCB, the obvious hiatus between the Middle Silurian and Middle Devonian in the Huangling area may correspond to the Early Paleozoic intracontinental orogeny of SCB. However, this event was well documented to the southeastern areas of the Jiangshan-Shaoxing fault, mainly along the Wuyi-Yunkai belt (Lin et al., 2008, Faure et al., 2009, Charvet et al., 2010, Li et al., 2010 and Y.J. Wang et al., 2010). Moving to the NW, the deformation intensity is decreasing, and even absent. The Huangling massif is far away from the deformation domain of the Early Paleozoic orogeny.

The local discontinuity between the Middle and Late Triassic in the Huangling area was considered as a response to the so-called "Indosinian orogeny" of SCB (Meng and Li, 2003, Li et al., 2008 and Zhao et al., 2010). As mentioned in Section 1, this Early Mesozoic orogeny was widely developed around or inside the SCB, such as the Qinling-Dabie belt to the north of the Huangling massif (e.g. Faure et al., 1999 and Faure et al., 2003) and the XuefengshanJiuling belt in the central SCB (Chu et al., 2012a and Chu and Lin, 2013). Our other two MDD samples from the migmatite (JH71) and granodiorite (JH147) recorded this tectonic 
event, showing a prolonged cooling since Late Triassic, with undistinguished Late Mesozoic process (Figs. 9 and 10B). However, it seems that this widespread tectonic event weakly influenced the Huangling massif. The Huangling massif is located in a stable triangle area between the Qinling-Dabie belt and Xuefengshan-Jiuling belt, where the Triassic deformation was rather weaker than two other domains. Indeed, as a stable sedimentary platform, there is no significant angular unconformity in the Huangling area from ca. $750 \mathrm{Ma}$ until the Late Jurassic (Fig. 3). According to lithology and paleontology, the Upper Triassic and Jurassic series in Zigui and Dangyang basins are completely comparable (BGMRHB, 1990). Thus, accompanied by the Triassic regression, effect of the Indosinian orogeny is expressed as a locally slight vertical uplift of the crust in the Huangling area, but which did not built the antiformal shape of the massif (Fig. 10A).

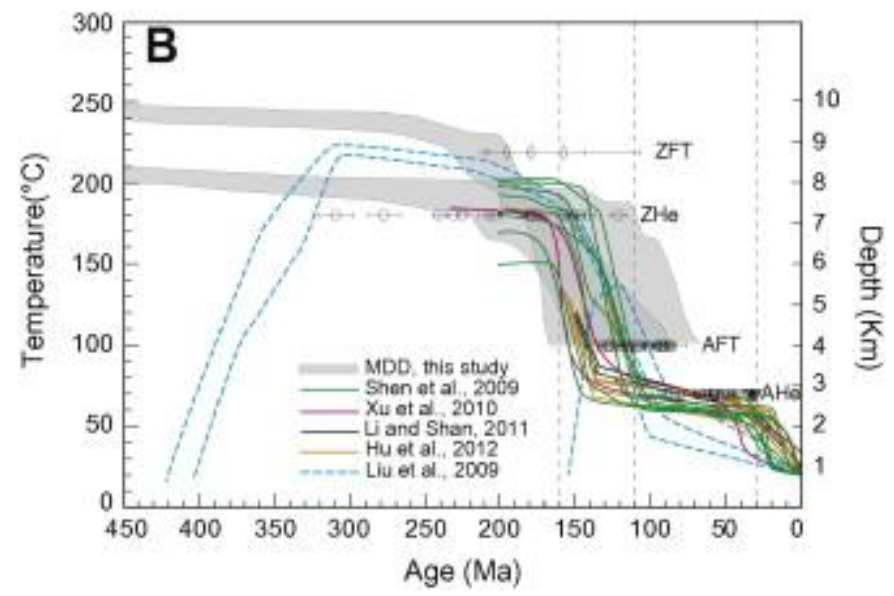

Fig. 10B. : Cooling history of the Huangling massif from K-feldspar MDD modeling (this study) and AFT modeling (Liu et al., 2009, Shen et al., 2009, Xu et al., 2010, Li and Shan, 2011 and $\mathrm{Hu}$ et al., 2012). It indicates a thermal history with four major phases: a prolonged slow cooling until $160 \mathrm{Ma}$, a obvious enhanced cooling with a rate of $2-3{ }^{\circ} \mathrm{C} / \mathrm{Ma}$ during 160 $110 \mathrm{Ma}$, a slow cooling during $110-30 \mathrm{Ma}$ interval with a rate of $0.2-0.3{ }^{\circ} \mathrm{C} / \mathrm{Ma}$, and a final increased cooling since $30 \mathrm{Ma}$ with a rate about $1^{\circ} \mathrm{C} / \mathrm{Ma}$. AHe, AFT, ZHe and ZFT ages (Fig. $8 \mathrm{~B}$ ) are plotted at their closure temperatures of $70^{\circ} \mathrm{C}, 100{ }^{\circ} \mathrm{C}, 180^{\circ} \mathrm{C}$ and $220{ }^{\circ} \mathrm{C}$, respectively.

The detailed cooling history since $200 \mathrm{Ma}$ of the Huangling massif is constrained by FT and (U-Th)/He data (Shen et al., 2009, Xu et al., 2010, Li and Shan, 2011 and Hu et al., 2012; Fig. 10B). AFT thermal modeling results from the dome core indicate that the Huangling massif recorded a stable stage before $160 \mathrm{Ma}$ and an obvious cooling process between 160 and $110 \mathrm{Ma}$ with a rate of $2-3{ }^{\circ} \mathrm{C} / \mathrm{Ma}$. A similar thermal modeling result has been shown in the work of Richardson et al. (2010), the increasing cooling after 40 Ma was been considered as the onset of incision in the Three Gorges. Moreover, three AFT modeling for the sedimentary rocks on the eastern flank of the Huangling massif revealed a cooling rate of 1.9$2.7^{\circ} \mathrm{C} / \mathrm{Ma}$ during 165-100 Ma (Liu et al., 2009; Fig. 10B). Instead, Hu et al. (2006) suggested that the significant cooling event occurred during 100 and $40 \mathrm{Ma}$ with a cooling rate of $2.5^{\circ} \mathrm{C} / \mathrm{Ma}$, but the GOF (goodness of fit) between the measured and modeled fissiontrack length distributions and ages are below 0.5. On the assumption that the geothermal gradient is a constant of $25^{\circ} \mathrm{C} / \mathrm{km}$, the unroofing depth of the massif during the interval of 160-110 Ma was approximately $5 \mathrm{~km}$ (Fig. 10B). 
Recent sedimentary evidence also supports that the Huangling massif experienced considerable uplifting during the Late Jurassic to Early Cretaceous. Before the Late Jurassic, the Zigui and Dangyang basins probably connected with each other based on paleogeography (Liu et al., 2005). Paleocurrents analysis of the Zigui basin indicates that the Huangling massif began to provide detrital material since Late Jurassic (Qu et al., 2009). To the southeast of Huangling massif, the results of detrital zircon $\mathrm{U}-\mathrm{Pb}$ ages from the Cretaceous sediments reveal that the denudation of the Kongling complex and its overlying strata was active during the deposition of the Lower Cretaceous, and the Huangling granite was exposed at the surface during the Late Cretaceous (Shen et al., 2012). The uplifting of the Huangling massif led to the atrophy of the Zigui basin on its western flank, while the onset of rifting in the Dangyang basin on its eastern flank. It was also resulted in the prominent angular unconformity between Late Jurassic and Early Cretaceous.

\subsection{When did the Huangling massif come into being?}

On the western and eastern sides of the dome, the deformation due to gravitational décollement and layer-parallel slipping occurred in response to its uplifting (Fig. 4, Fig. 6 and Fig. 7). But the northern and southern sides of the dome are not involved into such a deformation (Fig. 2). The uplifting time of the Huangling massif is still controversial: Early Mesozoic (Dai, 1996 and Xu et al., 2004), unprecisely determined between the Late Triassic to Early Cretaceous (Wang et al., 2003), or sometime between $165 \mathrm{Ma}$ and $98 \mathrm{Ma}$ as indicated by AFT data (Liu et al., 2009, Shen et al., 2009, Xu et al., 2010, Li and Shan, 2011 and Hu et al., 2012). On the basis of regional tectonics, Ge et al. (2010) considered that this antiform shaped at ca. 24.6 Ma, corresponding to the regional angular unconformity in the end of the Paleogene. Our field work indicates that these "gravity-driven collapse folds" with east-west polarity are observed in all the strata of pre-Cretaceous age, since the Cretaceous graben and half-graben basins superimposed unconformably on these folded strata (Fig. 2 and Fig. 4). As discussed above, the Huangling area was not significantly involved into any tectonic events between the Sinian (Neoproterozoic) and Jurassic. Cooling history also reveals that the Huangling massif experienced an important uplift process around 160-110 Ma (Fig. 10A and Fig. 10B). These geochronological and sedimentary constraints are in good agreement with our structural observations, which argue that the main deformation in the Huangling massif developed from the Late Jurassic to Early Cretaceous.

\subsection{Compressional or extensional setting model}

The origin of the Huangling massif was variously interpreted by previous workers either in terms of compression or extension. According to investigations on the tectonic evolution of the Jianghan basin, a westward escape of the Huangling massif related to the Early Mesozoic opposite-directed thrusting of the Qinling-Dabie belt and the Jiuling belt has been suggested (Fig. 11A; Dai, 1996 and Xu et al., 2004). This model might well explain the geometry of the Huangling massif, which is an asymmetric antiform with its eastern side more gently dipping than its western side. In fact, far from the northern and southern sides of the Huangling massif, we observed a nearly $\mathrm{N}-\mathrm{S}$ directed trust deformation, which is probably the response to the Triassic compression in the Qinling-Dabie belt to the north and the XuefengshanJiuling intracontinental belt to the south, respectively (Fig. 1, see also Chu and Lin, 2013, this issue). However, there is a time discrepancy between the Triassic deformation and the Late Jurassic-Early Cretaceous tectonics in the Huangling massif. Moreover, it is noteworthy that the hinge of Huangling massif is nearly $\mathrm{N}-\mathrm{S}$ trending, which is sub-parallel to the shortening direction of the Triassic deformation, the W-directed thrust faults and folds are not well 
developed around the Huangling massif. Cooling history shows that uplifting of the Huangling massif occurred between $160 \mathrm{Ma}$ and $110 \mathrm{Ma}$, which is longtime after the Triassic events. Nevertheless, asymmetry of the Huangling massif can be interpreted as a kind of ramp anticline developed on top of a blind thrust as depicted in Fig 11A. If this is the case, the westward thrusting would have taken place in the Late Jurassic to Early Cretaceous.

A
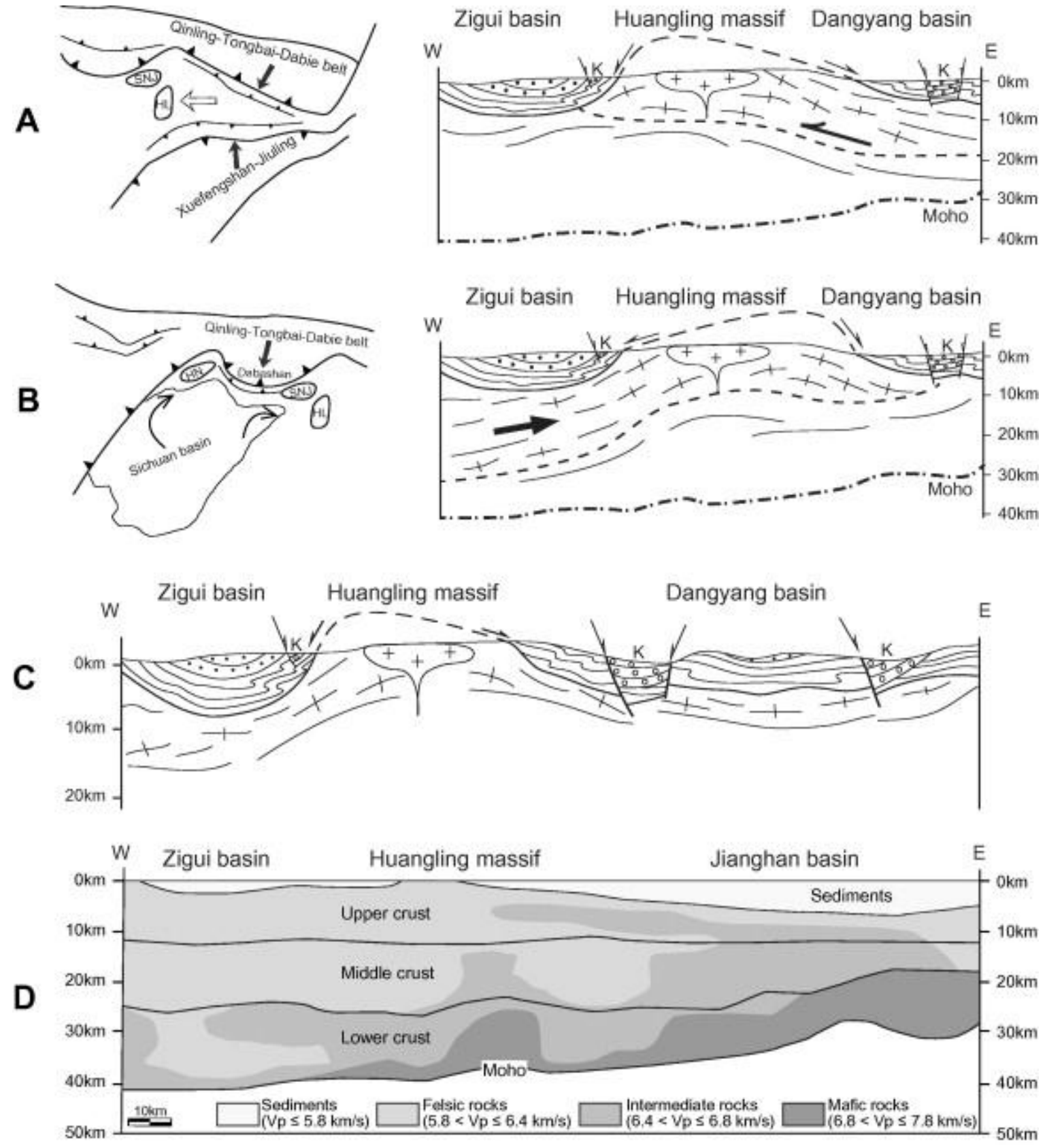

Fig. 11. : Three possible tectonic models for origin of the Huangling massif. (A) Westward thrusting; (B) Eastward extrusion; (C) Extensional uplifting; (D) The profile of $P$-wave crustal velocity structure from wide angle reflection across the Huangling massif (modified after Z.J. Zhang et al. (2009)).

Another model was recently put forward, namely the Late Mesozoic eastward extrusion due to its northward indentation and coeval clockwise rotation of the SCB (Fig. 11B; Wang et al., 
2003 and Meng et al., 2005). The Huangling massif was considered as one of the syntaxes related to the Dabashan orocline (Fig. 1; Hu et al., 2012, Shi et al., 2012 and Li et al., 2013). This model is well compatible with the age of the deformation related to uplifting of the massif. However, a problem arises as the eastward extrusion would lead to an opposite geometry of the Huangling massif with its western flank more gently dipping than the eastern one (Fig. 11B). Thus, this model is not compatible with our field observations (Fig. 4E).

Late Mesozoic extensional tectonics was widely spread on the eastern margin of Eurasian continent, which is indicated by a number of extensional domes, and syntectonic plutons bounded by ductile normal faults (e.g. Lin and Wang, 2006, T. Wang et al., 2011 and Lin et al., 2013). The temporal-spatial framework of the extensional tectonics brings a reasonable assumption that the Huangling area might have experienced the same geodynamic setting. Therefore, an extensional uplifting model is proposed here: the regional extension that occurred on the eastern margin of Eurasian continent is responsible for the origin of the Huangling massif. To some extent, this extension exhumed and tilted the Huangling massif (Fig. 11C). Accompanying this uplifting, a series of oppositely directed gravity-driven collapse folds developed on the western and eastern sides of the dome. From this view, the drag-folds in the sedimentary cover, and the formation of graben or half graben basins around the Huangling massif belong to the same extensional tectonics with a slight diachronism. However, it is worth to note that low-angle ductile normal faults or detachments are lacking between the basement and sedimentary cover. Also, syntectonic plutons coeval with extension as observed in more southeasterly part of the SCB (Fig. 1, e.g. Wugongshan, DayunshanMufushan, Hengshan), are absent in the Huangling area.

In the present state of knowledge, we cannot completely rule out the compressional tectonic model. Taking into account the geometry and the deformation styles of the Huangling massif presented in the previous sections, it appears that the extensional tectonic model is also plausible. In this case, the Huangling massif represents the westernmost case of the Late Mesozoic extensional tectonics in the SCB, as recognized elsewhere in many parts of the eastern Eurasian continent. Scope of destruction of the NCC is roughly bounded by the N-S Gravity Lineament, which was formed by diachronous lithospheric thinning since Early Cretaceous (Xu, 2007 and Zhu et al., 2011). Coincidentally, the Huangling massif that recorded a weak extension of the crust also lies in this N-S Gravity Lineament (Fig. 1). Thus it could be considered as an extensional structure developed in inland area of the stable Yangtze craton, which probably represents the western front of the Late Mesozoic lithospheric thinning of the SCB. This is also comparable with the deep crustal structure indicated by the $P$-wave crustal velocity from a wide angle reflection profile (Z.J. Zhang et al., 2009). The crustal thickness decreases from $42 \mathrm{~km}$ to $30 \mathrm{~km}$ across the Zigui basin, Huangling massif and Jianghan basin (Fig. 11D).

\section{Conclusions}

Available structural, sedimentary and geochronological data allow us to draw a general picture of the Huangling massif that appears as an N-S striking antiform. The Huangling massif recorded an inherited paleo-relief in the Yangtze craton around $750 \mathrm{Ma}$. The Early Paleozoic and Early Mesozoic orogenies of South China had no significant imprint on the architecture of the Huangling massif. The Neoproterozoic-Triassic strata on the western and eastern sides of the Huangling massif were involved in a series of oppositely directed gravitational décollements and layer-parallel slip surfaces that accommodated the uplifting. The subsequently brittle normal faulting controlled the deposition of the rift basin on its 
eastern flank. The involvement of the Late Jurassic strata and the unconformable superposition of the Early Cretaceous conglomerate indicate that the uplifting of the Huangling massif occurred between the Late Jurassic and Early Cretaceous, which is in agreement with a cooling process between $160 \mathrm{Ma}$ and $110 \mathrm{Ma}$ revealed by thermochronology. Perhaps because of its location in stable crust of the SCB, the deformation is rather weak and developed in response to its uplift. The extensional or compressional setting of the Huangling massif is not settled yet. If compressional, the anticline may develop on top of a speculated blind thrust. If extensional, this structure probably represents the western front of the Late Mesozoic lithospheric thinning in South China.

\section{Acknowledgements}

Field and laboratory expenses have been funded by the Chinese National 973 Project (No. 2009CB825008), National Natural Science Foundation of China (No. 41225009), Innovative Project of the Chinese Academy of Sciences (No. KZCX1-YW-15-1), and the Major National Science and Technology Project (No. 2011ZX05008-001). Jacques Charvet and Liangshu Shu are gratefully appreciated for their critical and constructive reviews.

\section{References}

BGMRHB, 1990

BGMRHB, 1990. Bureau of Geology and Mineral Resources of Hubei Province, Regional Geology of Hubei Province. Geological Publishing House, Beijing, pp. 1-705 (in Chinese with English abstract).

Burchfiel et al., 1995

B.C. Burchfiel, Z. Chen, Y. Liu, L.H. Royden

Tectonics of the Longmen Shan and adjacent regions

International Geology Review, 37 (1995), pp. 661-735

Carter and Clift, 2008

A. Carter, P. Clift

Was the Indosinian orogeny a Triassic mountain building or a thermotectonic reactivation event?

Comptes Rendus Géoscience, 340 (2008), pp. 83-93

Carter et al., 2001

A. Carter, D. Roques, C. Bristow, P. Kinny

Understanding Mesozoic accretion in Southeast Asia: significance of Triassic thermotectonism (Indosinian orogeny) in Vietnam

Geology, 29 (2001), pp. 211-214

Charvet et al., 1996

J. Charvet, L.S. Shu, Y.S. Shi, L.Z. Guo, M. Faure

The building of south China: collision of Yangzi and Cathaysia blocks, problems and tentative answers

Journal of Southeastern Asian Earth Science, 13 (1996), pp. 223-235

Charvet et al., 2010

J. Charvet, L.S. Shu, M. Faure, F. Choulet, B. Wang, H.F. Lu, N. Le Breton 
Structural development of the Lower Paleozoic belt of South China: genesis of an intracontinental orogen

Journal of Asian Earth Science, 39 (2010), pp. 309-330

Chen, 1999

A. Chen

Mirror thrusting in the South China Orogenic Belt: tectonic evidence from western Fujian, southeastern China

Tectonophysics, 305 (1999), pp. 497-519

Chen and Wilson, 1996

S.F. Chen, C.J.L. Wilson

Emplacement of the Longmen Shan Thrust-Nappe Belt along the eastern margin of the Tibetan Plateau

Journal of Structural Geology, 18 (1996), pp. 413-440

Chen et al., 1991

J.F. Chen, K.A. Foland, F.M. Xing, X. Xu, T.X. Zhou

Magmatism along the southeast margin of the Yangtze Block. Precambrian collision of the Yangtze and Cathaysia Blokcs of China

Geology, 19 (1991), pp. 815-818

Chen et al., 2013

K. Chen, S. Gao, Y.B. Wu, J.L. Guo, Z.C. Hu, Y.S. Liu, K.Q. Zong, Z.W. Liang, X.L. Geng

2.6-2.7 Ga crustal growth in Yangtze craton, South China

Precambrian Research, 224 (2013), pp. 472-490

Chu and Lin, 2013

Chu, Y., Lin, W., 2013. Phanerozoic polyorogenic deformation in southern Jiuling massif, northern South China block: constraints from structural analysis and geochronogy.

Journal of Asian Earth Sciences (this issue).

Chu et al., 2012a

Y. Chu, M. Faure, W. Lin, Q.C. Wang

Early Mesozoic Tectonics of the South China block: insights from the

Xuefengshan intracontinental orogen

Journal of Asian Earth Sciences, 61 (2012), pp. 199-220

Chu et al., 2012b

Y. Chu, M. Faure, W. Lin, Q.C. Wang, W.B. Ji

Tectonics of the Middle Triassic intracontinental Xuefengshan Belt, South China: new insights from structural and chronological constraints on the basal décollement zone

International Journal of Earth Sciences, 101 (2012), pp. 2125-2150

Chu et al., 2012c

Y. Chu, W. Lin, M. Faure, Q.C. Wang, W.B. Ji

Phanerozoic tectonothermal events of the Xuefengshan Belt, central South China: implications from $\mathrm{U} / \mathrm{Pb}$ age and $\mathrm{Lu} / \mathrm{Hf}$ determinations of granites

Lithos, 150 (2012), pp. 243-255 
Condon et al., 2005

D. Condon, M. Zhu, S. Bowring, W. Wang, A. Yang, Y. Jin

$\mathrm{U}-\mathrm{Pb}$ ages from the Neoproterozoic Doushantuo Formation, China

Science, 308 (2005), pp. 95-98

Dai, 1996

S.W. Dai

Discussion on the regional structural features of Jianghan basin since Indosinian movement

Journal of Geomechanics, 2 (1996), pp. 80-84 (in Chinese with English abstract)

Faure et al., 1996

M. Faure, Y. Sun, L. Shu, P. Monié, J. Charvet

Extensional tectonics within a subduction-type orogen. The case study of the

Wugongshan dome (Jiangxi Province, SE China)

Tectonophysics, 263 (1996), pp. 77-108

Faure et al., 1998

M. Faure, W. Lin, Y. Sun

Doming in the southern foreland of the Dabieshan (Yangtse block, China)

Terra Nova, 10 (1998), pp. 307-311

Faure et al., 1999

M. Faure, W. Lin, L. Shu, Y. Sun, U. Schärer

Tectonics of the Dabieshan (eastern China) and possible exhumation mechanism of ultrahigh-pressure rocks

Terra Nova, 11 (1999), pp. 251-258

Faure et al., 2003

M. Faure, W. Lin, U. Schärer, L. Shu, Y. Sun, N. Arnaud

Continental subduction and exhumation of UHP rocks. Structural and

geochronological insights from the Dabieshan (East China)

Lithos, 70 (2003), pp. 213-241

Faure et al., 2009

M. Faure, L. Shu, B. Wang, J. Charvet, F. Choulet, P. Monie

Intracontinental subduction: a possible mechanism for the Early Palaeozoic

Orogen of SE China

Terra Nova, 21 (2009), pp. 360-368

Feng et al., 1991

D.Y. Feng, Z.C. Li, Z.C. Zhang

Emplace age and isotope characteristics of massives in the south of Huangling granitoids

Hubei Geology, 5 (1991), pp. 1-12 (in Chinese with English abstract)

Gao and Zhang, 2009

W. Gao, C.H. Zhang

Zircon SHRIMP U-Pb ages of the Huangling granite and the tuff beds from Liantuo Formation in the Three Gorges area of Yangtze River, China and its geological significance 
Geological Bulletin of China, 28 (2009), pp. 45-50 (in Chinese with English abstract)

Gao et al., 1999

S. Gao, W.L. Ling, Y.M. Qiu, L. Zhou, G. Hartmann, K. Simon

Contrasting geochemical and $\mathrm{Sm}-\mathrm{Nd}$ isotopic compositions of Archean metasediments from the Kongling high-grade terrain of the Yangtze craton: evidence for cratonic evolution and redistribution of REE during crustal anatexis Geochimica et Cosmochimica Acta, 63 (13-14) (1999), pp. 2071-2088

Gao et al., 2011

S. Gao, J. Yang, L. Zhou, M. Li, Z.C. Hu, J.L. Guo, H.L. Yuan, H.J. Gong, G.Q. Xiao, J.Q. Wei Age and growth of the Archean Kongling terrain, South China, with emphasis on 3.3 Ga granitoid gneisses

American Journal of science, 311 (2011), pp. 153-182

Ge et al., 2010

X.H. Ge, M.P. Wang, J.L. Liu

Redefining the Sichuan Movement and the age and background of Qingzang plateau's first uplift: the implication of Huangling anticline and its enlightenment Earth Science Frontiers, 17 (2010), pp. 206-217 (in Chinese with English abstract)

Gilder et al., 1991

S. Gilder, G.R. Keller, M. Luo

Timing and spatial distribution of rifting in China

Tectonophysics, 197 (1991), pp. 225-243

Gilder et al., 1996

S.A. Gilder, J. Gill, R.S. Coe, X.X. Zhao, Z.W. Liu, G.X. Wang, K.R. Yuan, W.L. Liu, G.D. Kuang, H.R. Wu

Isotopic and paleomagnetic constraints on the Mesozoic tectonic evolution of south China

Journal of Geophysical Research, 101 (1996), pp. 16137-16154

Guo et al., 1989

L.Z. Guo, Y.S. Shi, H.F. Lu, R.S. Ma, H. Dong

The pre-Devonian tectonic patterns and evolution of South China

Journal of Southeast Asian Earth Sciences, 3 (1989), pp. 87-93

Hacker et al., 2000

B.R. Hacker, L. Ratschbacher, L.E. Webb, M. McWilliams, T. Ireland, S. Dong, A. Calvert, H.R. Wenk

Exhumation of ultrahigh-pressure continental crust in east-central China: Late Triassic-Early Jurassic tectonic unroofing Journal of Geophysical Research, 105 (2000), pp. 13339-13364

Hsü et al., 1988

K.J. Hsü, S. Sun, J.L. Li, H.H. Chen, H.P. Peng, A.M.C. Şengör

Mesozoic overthrust tectonics in South China

Geology, 16 (1988), pp. 418-421 
Hsü et al., 1990

K.J. Hsü, J.L. Li, H.H. Chen, Q.C. Wang, S. Sun, A.M.C. Şengör

Tectonics of South China: key to understanding West pacific geology

Tectonophysics, 183 (1990), pp. 9-39

Hu et al., 1989

S.L. Hu, H.Y. Liu, S.S. Wang, W.H. Hu, H.Q. Sang, J. Qiu

On the age of Sinian lower boundary inferred from the new ${ }^{40} \mathrm{Ar} /{ }^{39} \mathrm{Ar}$ data

Scientia Geologica Sinica, 1 (1989), pp. 16-25 (in Chinese with English abstract)

Hu et al., 2006

S.B. Hu, A. Raza, K. Min, B.P. Kohn, P.W. Reiners, R.A. Ketcham, J.Y. Wang, A.J.W.

Gleadow

Late Mesozoic and Cenozoic thermotectonic evolution along a transect from the north China craton through the Qinling orogen into the Yangtze craton, central China

Tectonics, 25 (2006), p. TC6009 http://dx.doi.org/10.1029/2006TC001985

Hu et al., 2012

J.M. Hu, H. Chen, H.J. Qu, G.L. Wu, J.X. Yang, Z.Y. Zhang

Mesozoic deformations of the Dabashan in the southern Qinling orogen, central

China

Journal of Asian Earth Sciences, 47 (2012), pp. 171-184

Huang, 1978

T.K. Huang

An outline of the tectonic characteristics of China

Ecologae Geologicae Helvetiae, 71 (1978), pp. 611-635

Ji et al., 2011

W.B. Ji, W. Lin, Y.H. Shi, Q.C. Wang, Y. Chu

Structure and evolution of the Early Cretaceous Dabieshan metamorphic core complex

Chinese Journal of Geology, 46 (2011), pp. 161-180 (in Chinese with English abstract)

Jiang et al., 2002

L.S. Jiang, T.L. Chen, Z.Y. Zhou

Several principal geological problems in Huangling

Hubei Geology and Mineral Resources, 16 (2002), pp. 8-13 (in Chinese with English abstract)

Jiao et al., 2009

W.F. Jiao, Y.B. Wu, S.H. Yang, M. Peng, J. Wang

The oldest basement rock in the Yangtze Craton revealed by zircon $\mathrm{U}-\mathrm{Pb}$ age and Hf isotope composition

Science in China (Series D), 52 (2009), pp. 1393-1399

Koppers, 2002

A.A.P. Koppers

ArArCALC — software for ${ }^{40} \mathrm{Ar} /{ }^{39} \mathrm{Ar}$ age calculations 
Computers \& Geosciences, 28 (2002), pp. 605-619

Lepvrier et al., 2008

C. Lepvrier, N. Van Vuong, H. Maluski, P. Truong Thi, T. Van Vu

Indosinian tectonics in Vietnam

Comptes Rendus Geoscience, 340 (2008), pp. 94-111

Li, 1998

Z.X. Li

Tectonic history of the major East Asian lithospheric blocks since the midProterozoic — a synthesis

American Geophysical Union, Geodynamics Series, 27 (1998), pp. 221-243

$\mathrm{Li}, 2000$

X.H. Li

Cretaceous magmatism and lithospheric extension in Southeast China

Journal of Asian Earth Sciences, 18 (2000), pp. 293-305

$\mathrm{Li}$ and $\mathrm{Li}, 2007$

Z.X. Li, X.H. Li

Formation of the 1300-km-wide intracontinental orogen and postorogenic magmatic province in Mesozoic South China: a flat-slab subduction model Geology, 35 (2007), pp. 179-182

Li and Shan, 2011

X.M. Li, Y.H. Shan

Diverse exhumation of the Mesozoic tectonic belt within the Yangtze Plate, China, determined by apatite fission-track thermochronology

Geosciences Journal, 15 (2011), pp. 349-357

Li et al., 2002

Z.C. Li, G.H. Wang, Z.C. Zhang

Isotopic age spectrum of the Huangling granitic batholith, western Hubei Geology and Mineral Resources of South China, 3 (2002), pp. 19-28 (in Chinese with English abstract)

Li et al., 2004

Z.X. Li, D.A.D. Evans, S. Zhang

A $90^{\circ}$ spin on Rodinia: possible causal links between the Neoproterozoic supercontinent, superplume, true polar wander and low-latitude glaciations Earth and Planetary Science Letters, 220 (2004), pp. 409-421

Li et al., 2007

Y.L. Li, H.W. Zhou, X.H. Li, Q.H. Luo

${ }^{40} \mathrm{Ar}-{ }^{39} \mathrm{Ar}$ plateau ages of biotite and amphibole from tonalite of Huangling granitoids and their cooling curve

Acta Petrologica Sinica, 23 (2007), pp. 1067-1074 (in Chinese with English abstract)

Li et al., 2008

X.B. Li, C.S. Wang, A. Liu 
Sedimentary response to the Indosinian movement - a case study of the MidUpper Triassic in the Zigui basin, Hubei

Geology in China, 35 (2008), pp. 984-991 (in Chinese with English abstract)

Li et al., 2009

X.H. Li, W.X. Li, Z.X. Li, C.H. Lo, J. Wang, M.F. Ye, Y.H. Yang

Amalgamation between the Yangtze and Cathaysia Blocks in South China: constraints from SHRIMP U-Pb zircon ages, geochemistry and $\mathrm{Nd}-\mathrm{Hf}$ isotopes of the Shuangxiwu volcanic rocks

Precambrian Research, 174 (2009), pp. 117-128

Li et al., 2010

Z.X. Li, X.H. Li, J.A. Wartho, C. Clark, W.X. Li, C.L. Zhang, C. Bao

Magmatic and metamorphic events during the early Paleozoic Wuyi-Yunkai orogeny, southeastern South China: new age constraints and pressure-temperature conditions

Geological Society of America Bulletin, 122 (2010), pp. 772-793

Li et al., 2011

S.Z. Li, M. Santosh, G.C. Zhao, G.W. Zhang, C. Jin

Intracontinental deformation in a frontier of super-convergence: a perspective on the tectonic milieu of the South China Block

Journal of Asian Earth Sciences, 49 (2011), pp. 313-329

Li et al., 2012

S.Z. Li, G.C. Zhao, L.M. Dai, X. Liu, L.H. Zhou, M. Santosh, Y.H. Suo

Mesozoic basins in eastern China and their bearing on the deconstruction of the North China Craton

Journal of Asian Earth Sciences, 47 (2012), pp. 64-79

Li et al., 2013

J.H. Li, Y.Q. Zhang, S.W. Dong, W. Shi

Structural and geochronological constraints on the Mesozoic tectonic evolution of the North Dabashan zone, South Qinling, central China

Journal of Asian Earth Sciences, 64 (2013), pp. 99-114

Lin and Wang, 2006

W. Lin, Q.C. Wang

Late Mesozoic extensional tectonics in North China block: a crustal response to the lithosphere removal of North China Craton?

Bulletin de la Société Géologique de France, 177 (2006), pp. 287-297

Lin et al., 2000

W. Lin, M. Faure, P. Monié, U. Schärer, L.S. Zhang, Y. Sun

Tectonics of SE China, new insights from the Lushan massif (Jiangxi Province)

Tectonics, 19 (2000), pp. 852-871

Lin et al., 2008

W. Lin, Q.C. Wang, K. Chen

Phanerozoic tectonics of south China block: new insights from the polyphase

deformation in the Yunkai massif 
Tectonics, 27 (2008), p. TC6004 http://dx.doi.org/10.1029/2007TC002207

Lin et al., 2009

W. Lin, Y.H. Shi, Q.C. Wang

Exhumation tectonics of the HP-UHP orogenic belt in Eastern China: new structural-petrological insights from the Tongcheng massif, Eastern Dabieshan Lithos, 109 (2009), pp. 285-303

Lin et al., 2013

W. Lin, M. Faure, Y. Chen, W.B. Ji, F. Wang, L. Wu, N. Charles, Q.C. Wang

Late Mesozoic compressional to extensional tectonics in the Yiwulüshan massif, NE China and its bearing on the evolution of the Yinshan-Yanshan orogenic belt Part I: structural analyses and geochronological constraints

Gondwana Research, 23 (2013), pp. 54-77

Ling et al., 1998

W.L. Ling, S. Gao, H.F. Zhang, L. Zhou, Z.B. Zhao

An Sm-Nd isotopic dating study of the Archean Kongling Complex in the Huangling area of the Yangtze Craton

Chinese Science Bulletin, 43 (1998), pp. 1187-1191

Ling et al., 2001

W.L. Ling, S. Gao, B.R. Zhang, L. Zhou, Q.D. Xu

The recognizing of ca. $1.95 \mathrm{Ga}$ tectono-thermal event in Kongling nucleus and its significance for the evolution of Yangtze Block

South China. Chinese Science Bulletin, 46 (2001), pp. 326-329

Ling et al., 2006

W.L. Ling, S. Gao, J.P. Cheng, L.S. Jiang, H.L. Yuan, Z.C. Hu

Neoproterozoic magmatic events within the Yangtze continental interior and along its northern margin and their tectonic implication: constraint from the ELA-

ICPMS U-Pb geochronology of zircons from the Huangling and Hannan complexes

Acta Petrologica Sinica, 22 (2006), pp. 387-396 (in Chinese with English abstract)

Liu et al., 2005

S.F. Liu, R. Steel, G.W. Zhang

Mesozoic sedimentary basin development and tectonic implication, northern Yangtze Block, eastern China: record of continent-continent collision Journal of Asian Earth Sciences, 25 (2005), pp. 9-27

Liu et al., 2008

X.M. Liu, S. Gao, C.R. Diwu, W.L. Ling

Precambrian growth of Yangtze craton as revealed by detrital zircon studies

American Journal of Science, 308 (2008), pp. 421-468

Liu et al., 2009

H.J. Liu, C.H. Xu, Z.Y. Zhou, R.A. Donelick

Detrital apatite fission track thermochronological constraints on the formation of the Huangling uplift (165-100 Ma)

Progress in Natural Science, 19 (2009), pp. 1326-1332 (in Chinese) 
Lovera et al., 1997

O.M. Lovera, M. Grove, T.M. Harrison, K.I. Mahon

Systematic analysis of K-feldspar ${ }^{40} \mathrm{Ar} /{ }^{39} \mathrm{Ar}$ step heating results: I. Significance of activation energy determinations

Geochimica et Cosmochimica Acta, 61 (1997), pp. 3171-3192

Lovera et al., 2002

O.M. Lovera, M. Grove, T.M. Harrison

Systematic analysis of K-feldspar ${ }^{40} \mathrm{Ar} /{ }^{39} \mathrm{Ar}$ step heating results II: Relevance of laboratory argon diffusion properties to nature

Geochimica et Cosmochimica Acta, 66 (2002), pp. 1237-1255

Ma et al., 1984

G.G. Ma, H.Q. Li, Z.C. Zhang

An investigation of the age limits of the Sinian System in South China

Bulletin of Yichang Institute of Geology and Mineral Resources, 8 (1984), pp. 129 (in Chinese with English abstract)

Ma et al., 1997

D.Q. Ma, Z.C. Li, Z.F. Xiao

The constitute, geochronology and geologic evolution of the Kongling complex, western Hubei

Acta Geoscientia Sinica, 18 (1997), pp. 233-241 (in Chinese with English abstract)

Ma et al., 2002

D.Q. Ma, S.H. Du, Z.F. Xiao

The origin of Huangling granite batholiths

Acta Petrologica et Mineralogica, 21 (2002), pp. 151-161 (in Chinese with

English abstract)

M. Mattauer, Ph. Matte, J. Malavieille, P. Tapponnier, H. Maluski, Z.Q. Xu, Y.L. Lu, Y.Q. Tang

Tectonics of Qinling belt: build-up and evolution of eastern Asia

Nature, 317 (1985), pp. 496-500

McDougall and Harrison, 1999

I. McDougall, T.M. Harrison

Geochronology and Thermochronology by the ${ }^{40} \mathrm{Ar} /{ }^{39} \mathrm{Ar}$ Method

Oxford University Press, Oxford (1999) pp. 1-269

Meng and Li, 2003

F.S. Meng, X.B. Li

Meticulous correlation of Upper Triassic Series on the eastern and western limbs of the Huangling dome, western Hubei

Geology and Mineral Resources of South China, 4 (2003), pp. 60-65 (in Chinese with English abstract)

Meng et al., 2003

Q.R. Meng, J.M. Hu, J.Q. Jin, Y. Zhang, D.F. Xu 
Tectonics of the Late Mesozoic wide extension basin system in the ChinaMongolia border region

Basin Research, 15 (2003), pp. 397-415

Meng et al., 2005

Q.R. Meng, E. Wang, J.M. Hu

Mesozoic sedimentary evolution of the northwest Sichuan basin: implication for continued clockwise rotation of the South China block

Geological Society of America Bulletin, 117 (2005), pp. 396-410

Menzies et al., 2007

M. Menzies, Y.G. Xu, H.F. Zhang, W.M. Fan

Integration of geology, geophysics and geochemistry: a key to understanding the North China Craton

Lithos, 96 (2007), pp. 1-21

Peng et al., 2012

S.B. Peng, T.M. Kusky, X.F. Jiang, L. Wang, J.P. Wang, H. Deng

Geology, geochemistry, and geochronology of the Miaowan ophiolite, Yangtze craton: implications for South China's amalgamation history with the Rodinian supercontinent

Gondwana Research, 21 (2012), pp. 577-597

Qiu et al., 2000

Y.M. Qiu, S. Gao, N.J. McNaughton, D.I. Groves, W. Ling

First evidence of $>3.2$ Ga continental crust in the Yangtze craton of south China and its implications for Archean crustal evolution and Phanerozoic tectonics

Geology, 28 (2000), pp. 11-14

Qu et al., 2009

H.J. Qu, J.M. Hu, J.J. Cui, G.L. Wu, M. Tian, W. Shi, S.L. Zhao

Jurassic sedimentary filling process of Zigui basin on the eastern section of Daba mountain tectonic belt and its structural evolution

Acta Geologica Sinica, 83 (2009), pp. 1254-1268 (in Chinese with English abstract)

Ratschbacher et al., 2000

L. Ratschbacher, B.R. Hacker, L.E. Webb, M. McWilliams, T. Ireland, S. Dong, A. Clavert, D. Chateigner, H.R. Wenk

Exhumation of the ultrahigh-pressure continental crust in east central China: cretaceous and Cenozoic unroofing and the Tan-Lu fault

Journal of Geophysical Research, 105 (2000), pp. 13303-13338

Ratschbacher et al., 2003

L. Ratschbacher, B.R. Hacker, A. Calvert, L.E. Webb, J.C. Grimmer, M.O. McWilliams, T. Ireland, S. Dong, J. Hu

Tectonics of the Qinling (central China): tectonostratigraphy, geochronology, and deformation history

Tectonophysics, 366 (2003), pp. 1-53

Ren et al., 2002 
J. Ren, K. Tamaki, S. Li, J. Zhang

Late Mesozoic and Cenozoic rifting and its dynamic setting in Eastern China and adjacent areas

Tectonophysics, 344 (2002), pp. 175-205

Richardson et al., 2010

N.J. Richardson, A.L. Densmore, D. Seward, M. Wipf, L. Yong

Did incision of the Three Gorges begin in the Eocene?

Geology, 38 (2010), pp. 551-554

Roger et al., 2010

F. Roger, M. Jolivet, J. Malavieille

The tectonic evolution of the Songpan-Garzê (North Tibet) and adjacent areas from Proterozoic to present: a synthesis

Journal of Asian Earth Sciences, 39 (2010), pp. 254-269

Shen et al., 2009

C.B. Shen, L.F. Mei, Z.Q. Liu, S.H. Xu

Apatite and zircon fission track data, evidences for the Mesozoic-Cenozoic uplift of Huangling dome, central China

Journal of Mineralogy and Petrology, 29 (2009), pp. 54-60 (in Chinese with

English abstract)

Shen et al., 2012

C.B. Shen, L.F. Mei, L. Peng, Y.Z. Chen, Z. Yang, G.F. Hong

LA-ICPMS U-Pb zircon age constraints on the provenance of Cretaceous

sediments in the Yichang area of the Jianghan Basin, central China

Cretaceous Research, 34 (2012), pp. 172-183

Shi et al., 2012

W. Shi, Y. Zhang, S. Dong, J. Hu, M. Wiesinger, L. Ratschbacher, J. Jonckheere, J. Li, M.

Tian, H. Chen, G. Wu, L. Ma, H. Li

Intra-continental Dabashan orocline, southwestern Qinling, Central China

Journal of Asian Earth Sciences, 46 (2012), pp. 20-38

Shu and Charvet, 1996

L.S. Shu, J. Charvet

Kinematics and geochronology of the Proterozoic Dongxiang-Shexian ductile hear zone: with HP metamorphism and ophiolitic melange (Jiangnan Region, China)

Tectonophysics, 267 (1996), pp. 291-302

Shu et al., 2008

L.S. Shu, M. Faure, B. Wang, X.M. Zhou, B. Song

Late Paleozoic-Early Mesozoic geological features of South China: response to the Indosinian collision events in Southeastern Asia

Comptes Rendus Geoscience, 340 (2008), pp. 151-165

Shu et al., 2009

L.S. Shu, X.M. Zhou, P. Deng, B. Wang, S.Y. Jiang, J.H. Yu, X.X. Zhao

Mesozoic tectonic evolution of the Southeast China Block: new insights from basin analysis 
Journal of Asian Earth Science, 34 (2009), pp. 376-391

Shui, 1988

T. Shui

Tectonic framework of the continental basement of southeast China

Scientia Sinica (Series B), 31 (1988), pp. 885-896

Wang et al., 2001

D.Z. Wang, L.S. Shu, M. Faure, W.Z. Sheng

Mesozoic magmatism and granitic dome in the Wugongshan massif, Jingxi province and their genetiocl relationship to the tectonic events in southeast China Tectonophysics, 339 (2001), pp. 259-277

Wang et al., 2003

E. Wang, Q.R. Meng, B.C. Burchfiel, G.W. Zhang

Mesozoic large-scale lateral extrusion, rotation, and uplift of the Tongbai-Dabie shan belt in east China

Geology, 31 (2003), pp. 307-310

Wang et al., 2005

Y.J. Wang, Y.H. Zhang, W.M. Fan, T.P. Peng

Structural signatures and ${ }^{40} \mathrm{Ar} /{ }^{39} \mathrm{Ar}$ geochronology of the Indosinian Xuefengshan tectonic belt, South China Block

Journal of Structural Geology, 27 (2005), pp. 985-998

Wang et al., 2006

F. Wang, H.Y. He, R.X. Zhu, H.Q. Sang, Y.L. Wang, L.K. Yang

Intercalibration of international and domestic ${ }^{40} \mathrm{Ar}-{ }^{39} \mathrm{Ar}$ dating standards

Science in China (Series D), 49 (2006), pp. 461-470

Wang et al., 2007

Y.J. Wang, W.M. Fan, P.A. Cawood, S.C. Ji, T.P. Peng, X.Y. Chen

Indosinian high-strain deformation for the Yunkaidashan tectonic belt, south

China: kinematics and ${ }^{40} \mathrm{Ar} /{ }^{39} \mathrm{Ar}$ geochronological constraints

Tectonics, 26 (2007), p. TC6008 http://dx.doi.org/10.1029/2007TC002099

Y.J. Wang et al., 2010

Y.J. Wang, F.F. Zhang, W.M. Fan, G.W. Zhang, S.Y. Chen, P.A. Cawood, A.M. Zhang

Tectonic setting of the South China Block in the early Paleozoic: resolving intracontinental and ocean closure models from detrital zircon $\mathrm{U}-\mathrm{Pb}$ geochronology

Tectonics, 29 (2010), p. TC6020 http://dx.doi.org/10.1029/2010TC002750

J. Wang et al., 2010

J. Wang, Y. Chu, W. Lin, Q.C. Wang

Structural geometry and the origin of the Huangling anticline

Chinese Journal of Geology, 45 (2010), pp. 615-625 (in Chinese with English abstract) 
T. Wang et al., 2011

Wang, T., Zheng, Y.D., Zhang, J.J., Zeng, L.S., Donskaya, T., Guo, L. and Li J.B., 2011a. Pattern and kinematic polarity of Late Mesozoic extension in continental NE Asia: perspectives from metamorphic core complexes, Tectonics, 30, TC6007, doi:10.1029/2011TC002896.

Y.S. Wang et al., 2011

Y.S. Wang, B.W. Xiang, G. Zhu, D.Z. Jiang

Structural and geochronological evidence for Early Cretaceous orogen-parallel extension of the ductile lithosphere in the northern Dabie orogenic belt, East China Journal of Structural Geology, 33 (2011), pp. 362-380

Wei et al., 2013

Wei, W., Chen, Y., Faure, M., Shi, Y.H., Martelet, G., Hou Q.L., Lin, W., Le Breton, N., Wang, Q.C., 2013. A multidisciplinary study on the emplacement mechanism of the Qingyang-Jiuhua Massif in Southeast China and its tectonic bearings. Part I: structural geology, AMS and paleomagnetism. Journal of Asian Earth Sciences (this issue).

Wu et al., 2005

F.Y. Wu, J.Q. Lin, S.A. Wilde, X.O. Zhang, J.H. Yang

Nature and significance of the Early Cretaceous giant igneous event in eastern China

Earth and Planetary Sciences Letters, 233 (2005), pp. 103-119

Wu et al., 2008

F.Y. Wu, Y.G. Xu, S. Gao, J.P. Zheng

Controversial on studies of the lithospheric thinning and craton destruction of North China

Acta Petrologica Sinica, 24 (2008), pp. 1145-1174 (in Chinese with English abstract)

Xu, 2007

Y.G. Xu

Diachronous lithospheric thinning of the North China Craton and formation of the Daxin'anling-Taihangshan gravity lineament

Lithos, 96 (2007), pp. 281-298

Xu et al., 2004

Z.Y. Xu, G. Lin, C.Y. Liu, Y.J. Wang, F. Guo

A discussion on amalgamation course between the South China and North China blocks: evidences from deformational characters in the Jianghan superimposed basin

Chinese Journal of Geology, 39 (2004), pp. 284-295 (in Chinese with English abstract)

Xu et al., 2010

C.H. Xu, Z.Y. Zhou, Y. Chang, F. Guillot

Genesis of Daba arcuate structural belt related to adjacent basement upheavals:

constraints from Fission-track and (U-Th)/He thermochronology

Science China - Earth Sciences, 53 (2010), pp. 1634-1646 
Yan et al., 2003

D.P. Yan, M.F. Zhou, H.L. Song, X.W. Wang, J. Malpas

Origin and tectonic significance of a Mesozoic multi-layer over-thrust system within the Yangtze Block (South China)

Tectonophysics, 361 (2003), pp. 239-254

Yan et al., 2011

D.P. Yan, M.F. Zhou, S.B. Li, G.Q. Wei

Structural and geochronological constraints on the Mesozoic-Cenozoic tectonic evolution of the Longmen Shan thrust belt, eastern Tibetan Plateau

Tetonics, 30 (2011), p. TC6005 http://dx.doi.org/10.1029/2011TC002867

Yang et al., 2008

J.H. Yang, F.Y. Wu, S.A. Wilde, E. Belousova, W.L. Griffin

Mesozoic decratonization of the North China block

Geology, 36 (2008), pp. 467-470

Yu and Ye, 1998

A.N. Yu, B.L. Ye

The affirmation of Dayunshan metamorphic core complex structure and its origin Hunan Geology, 17 (1998), pp. 81-84 (in Chinese with English abstract)

Zhang, 1986

H.D. Zhang

Preliminary analysis of the formation and tectonic evolution of Huangling anticline

Journal of Jianghan Petroleum Institute, 10 (1986), pp. 29-40 (in Chinese)

Zhang and Zheng, 1999

J.J. Zhang, Y.D. Zheng

Multistage extension and age dating of the Xiaoqinling Meatmorpic core complex, central China

Acta Geological Sinica, 73 (1999), pp. 139-147

Zhang et al., 1984

Zh.M. Zhang, J.G. Liou, R.G. Coleman

An outline of the plate tectonics of China

Geological Society of America Bulletin, 95 (1984), pp. 295-312

Zhang et al., 2006a

S.B. Zhang, Y.F. Zheng, Y.B. Wu, Z.F. Zhao, S. Gao, F.Y. Wu

Zircon isotope evidence for $\geqslant 3.5 \mathrm{Ga}$ continental crust in the Yangtze craton of

China

Precambrian Research, 146 (2006), pp. 16-34

Zhang et al., 2006b

S.B. Zhang, Y.F. Zheng, Y.B. Wu, Z.F. Zhao, S. Gao, F.Y. Wu

Zircon $\mathrm{U}-\mathrm{Pb}$ age and $\mathrm{Hf}-\mathrm{O}$ isotope evidence for Paleoproterozoic metamorphic event in South China

Precambrian Research, 151 (2006), pp. 265-288 
Zhang et al., 2006c

S.B. Zhang, Y.F. Zheng, Y.B. Wu, Z.F. Zhao, S. Gao, F.Y. Wu

Zircon $\mathrm{U}-\mathrm{Pb}$ age and $\mathrm{Hf}$ isotope evidence for $3.8 \mathrm{Ga}$ crustal remnant and episodic reworking of Archean crust in South China

Earth and Planetary Science Letters, 252 (2006), pp. 56-71

Zhang et al., 2008

S.B. Zhang, Y.F. Zheng, Z.F. Zhao, Y.B. Wu, H.L. Yuan, F.Y. Wu

Neoproterozoic anatexis of Archean Lithosphere: geochemical evidence from felsic to mafic intrusive at Xiaofeng in the Yangtze George, South China

Precambrian Research, 163 (2008), pp. 210-238

S.B. Zhang et al., 2009

S.B. Zhang, Y.F. Zheng, Z.F. Zhao, Y.B. Wu, H.L. Yuan, F.Y. Wu

Origin of TTG-like rocks from anatexis of ancient lower crust: geochemical evidence from Neoproterozoic granitoids in South China

Lithos, 113 (2009), pp. 347-368

Y.Q. Zhang et al., 2009

Y.Q. Zhang, X.B. Xu, D. Jia, L.S. Shu

Deformation record of the change from Indosinian collision-related tectonic system to Yanshanian subduction-related tectonic system in South China during the Early Mesozoic

Earth Science Frontiers, 16 (2009), pp. 234-247 (in Chinese with English abstract)

Z.J. Zhang et al., 2009

Z.J. Zhang, Z.M. Bai, W. Mooney, C.Y. Wang, X.B. Chen, E. Wang, J.W. Teng, N. Okaya Crustal structure across the Three Gorges area of the Yangtze platform, central China, from seismic refraction/wide-angle reflection data

Tectonophysics, 475 (2009), pp. 423-437

Zhang et al., 2012

Y.Q. Zhang, S.W. Dong, J.H. Li, J.J. Cun, W. Shi, J.B. Su, Y. Li

The new progress in the study of Mesozoic tectonics of south China

Acta Geoscientica Sinica, 33 (2012), pp. 257-279 (in Chinese with English abstract)

Zhao et al., 2006

F.Q. Zhao, W.P. Zhao, Y.C. Zuo, Z.H. Li

Zircon $\mathrm{U}-\mathrm{Pb}$ ages of the migmatites from Kongling complex

Geological Survey and Research, 29 (2006), pp. 81-85 (in Chinese with English abstract)

Zhao et al., 2010

X.M. Zhao, J.N. Tong, H.Z. Yao, Y. Tian

Sedimentary response to the Indosinian movement in Three Gorges area Journal of Palaeogeography, 12 (2010), pp. 177-184 (in Chinese with English abstract)

Zhou and Li, 2000

X.M. Zhou, W.X. Li 
Origin of Late Mesozoic igneous rocks in Southeastern China: implications for lithosphere subduction and underplating of mafic magmas

Tectonophysics, 326 (2000), pp. 269-287

Zhou et al., 2006

X.M. Zhou, T. Sun, W.Z. Shen, L.S. Shu, Y.L. Niu

Petrogenesis of Mesozoic granitoids and volcanic rocks in South China: a response to tectonic evolution

Episodes, 29 (2006), pp. 26-33

Zhu et al., 2010

G. Zhu, C.L. Xie, W. Chen, B.W. Xiang, Z.Q. Hu

Evolution of the Hongzhen metamorphic core complex: evidence for Early

Cretaceous extension in the eastern Yangtze craton, eastern China

Geological Society of America Bulletin, 122 (2010), pp. 506-516

Zhu et al., 2011

R.X. Zhu, L. Chen, F.Y. Wu, J.L. Liu

Timing, scale and mechanism of the destruction of the North China craton

Science China - Earth Sciences, 54 (2011), pp. 789-797 